الاتار المحتمله للاتضمام إلى منظمه التجارة العالميه وي مجال تحرير تجارة الخدمات الماليه وي النمو الاقتصادي: دراسات حاله

$$
\begin{aligned}
& \text { د.عبدالله هاضل الحيالي } \\
& \text { مدرس/ قسم الدراسات الاقتصادية و الاجتماعية/ مركز الدراسات الإقليمية / جامعة الموصل فليل } \\
& \text { مستخلص البحت }
\end{aligned}
$$

بعد تحرير تجارة الخدمات الماليه, وعلاهته بالنمو الاهتصادي حقلا خصـبـا فـي مضمار الاوتصاد الدولي. واهضت نتائج التحليل الكمي ان التحريـر المــالي للـــول

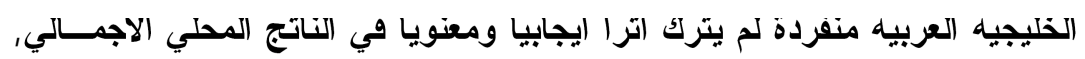

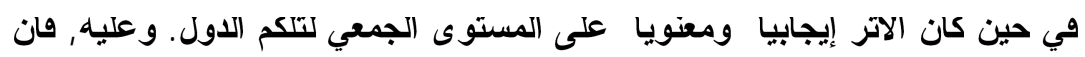

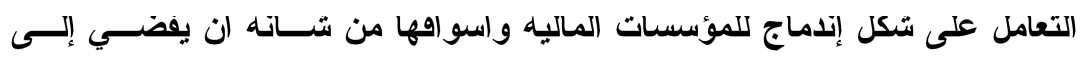

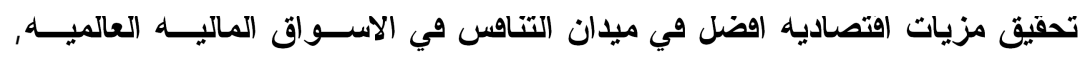
وتقويه موفقها التقاوضي في إطار الاسهام وي فرارات منظمه التجارة العالميه, بمال

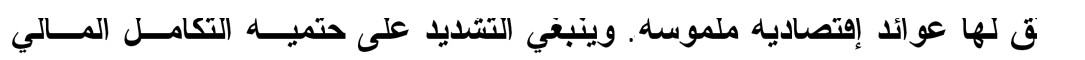

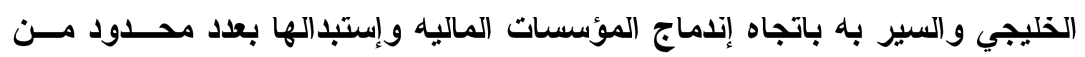
المؤسسات الماليه الضخمه التي تستطيع منافسه المؤسسات الماليه الاجنبيه بتــــل بلهل اهضل, في ظل تحرير تجارة الخدمات المالية. المقدمه: -

امسى الحديث عن الخدمات المالية ياخذ مجالا رحبــا فــي الادبيــات

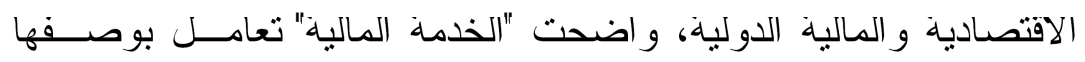

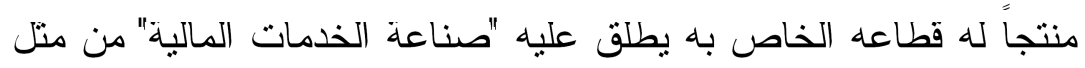

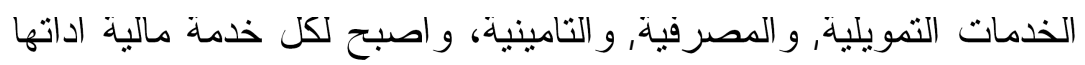

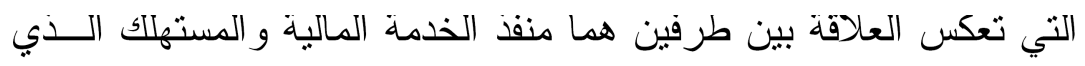


بطلبها. وبات تحرير الخدمات المالية من الموضو عات الاقتصادية المهمة

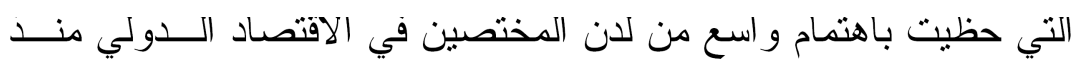

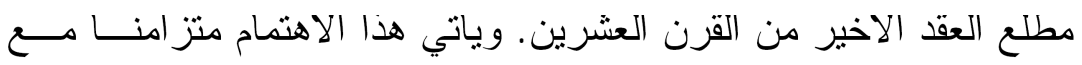

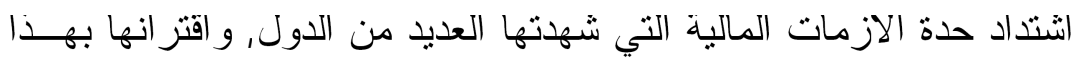

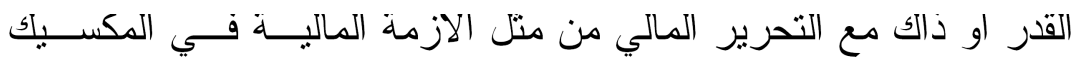
(1994 -1995), وفي جنوب شرق اسيا (1997), وفي البرازيــل (1998),

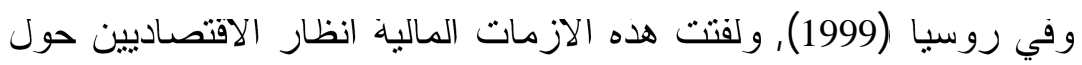

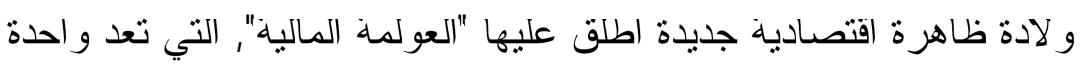

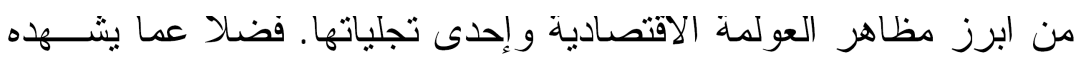

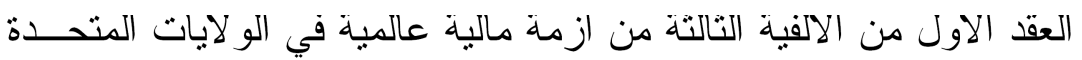

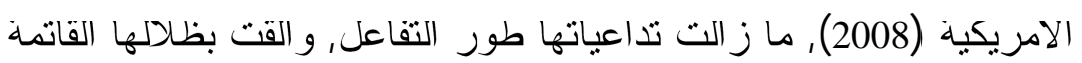
على اغلب الإقتصادات في العالم. كما تتبع اهمية تحرير الخدمات المالية,

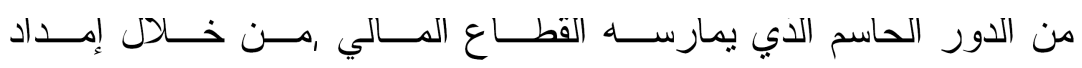
الاستتمار ات المحلية بمصادر النمو الإقتصـادي, فضلا عن نمــو تجـــارة

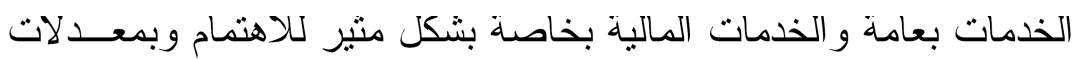

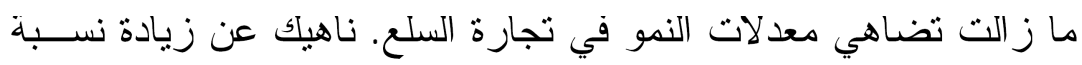

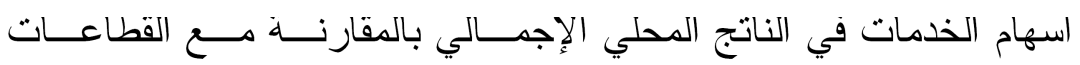
الاقتصادية الاخرى في معظم الدول. كما ان تحرير تجارة الخدمات بات بات باته

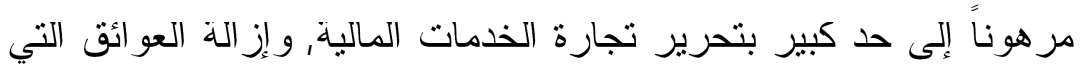

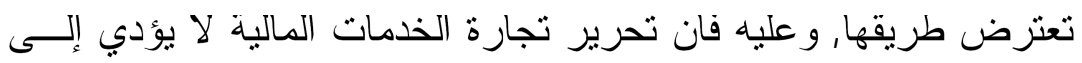

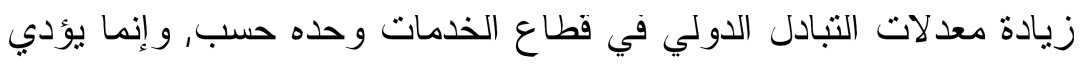

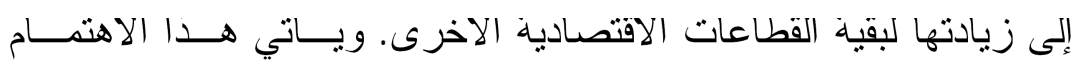

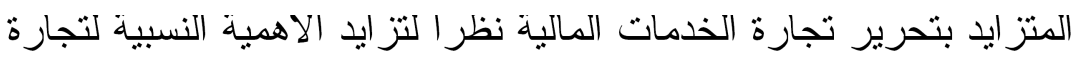
الخدمات المالية من اجمالي التجارة الدولية، ناهيك عن سياسات الانفتــاح 
[53]

و الإصلاح الاقتصادي التي تعزز من اهمية القطاع المالي, و التوجه الجاد

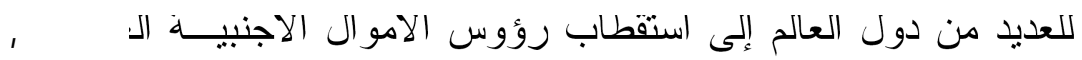

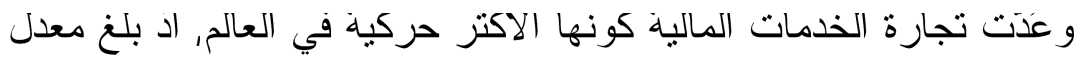

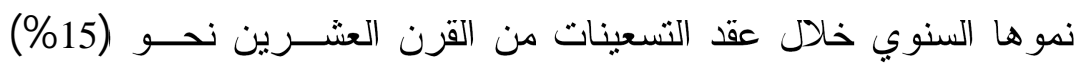

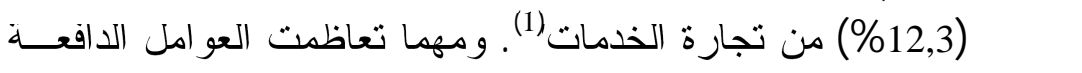
للبدء بتحرير تجارة الخدمات, بيد ان دو افع تحرير الخدمات المالبة يجد له له مسوغات اكثر كونه يوصف بالثرط المسبق الذي يتقدم سوق راس المال برمته, ويعد الشريان الحيوي الدي يسهل انتقال السلع و الخدمات.

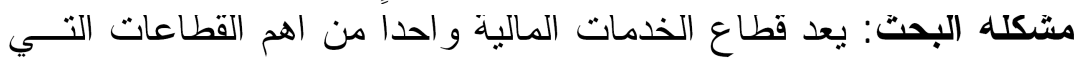

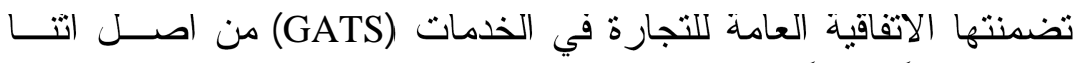

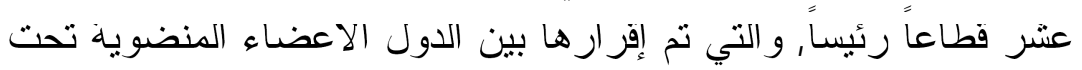

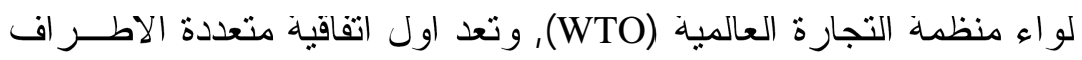

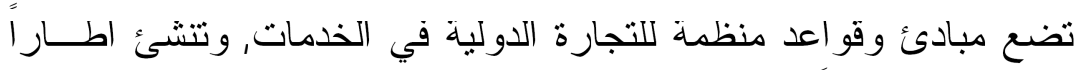

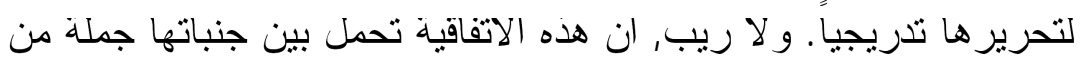

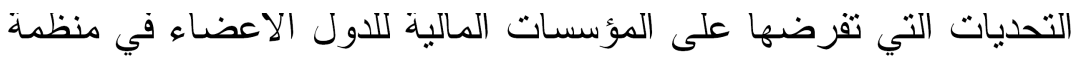

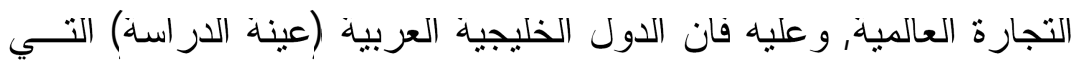
و افقت على الانضمام إلى منظمة التجارة العالمية، وتوقيعها على الاتفاقية

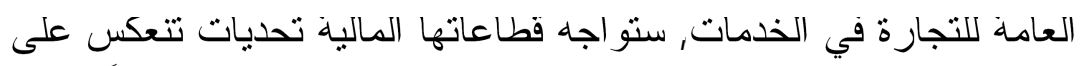

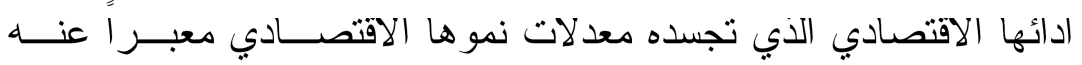

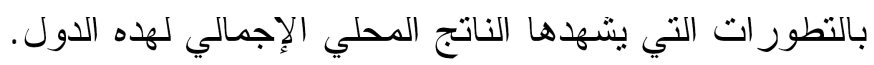
هدف البحث: - يهدف البحث إلى بيان اتر انضمام الدول الخليجية العربية إلى منظمة التجارة العالمية , وتبنيها سياسة تحرير تجارة الخدمات المالية في معدلات نمو ها الاقتصادي. ورضيه البحت: - تُمارس عملية تحرير تجارة الخدمات الماتية في في الدول الخليجية العربية اتارا سلبية في النمو الاقتصادي، لعدم قدرة مؤسساتها 
المالية على منافسة نظير اتها العالمية التي تتمتع بمهار ات عالية وبمزيات الإنتاج الكبير

منهج البحث: - يعتمد البحث الجمع بين الاســلوبين الوصــفي و الكمــيـ ويستند الاسلوب الوصفي على الدراسات النظرية, في حين يقوم الاسلوب الاب الكمي على القياس الاقتصادي الذي يهدف إلى قياس اثر انضمام الــدول

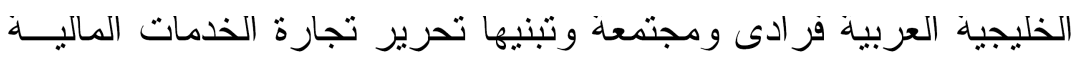
في النمو الاقتصادي وتحليله. وتم اعتماد المدة (1991-2007) لاسباب عدة ونجة

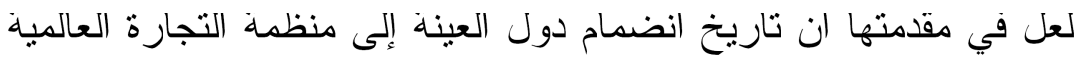
يقع ضمن هذه المدة, وقيامها بالتوقيع على اتفاقية التجارة في الخــدمات, فضـلا عن ان هذه المدة الزمنية شهدت جملة من النغيــر ات الاقتصــــادية المهمة ابرزها ذيوع ظاهرة العولمة المالية و انتشار ها، و إتباع دول العينة

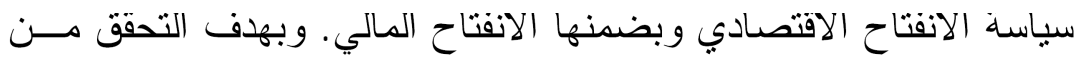
فرضية البحث جرى تقسيم البحث إلى اربعة محاور, اهتم المحور الاول

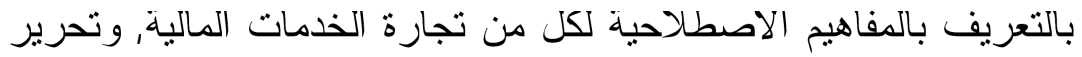

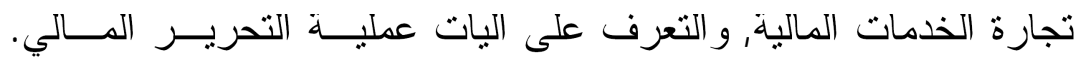
وتتاول المحور التاني مزيات تحرير تجارة الخدمات المالية وسـلـياتها, و انصب اهتمام المحور الثنالث على استعر اض الهم الدراسات التي تناولت

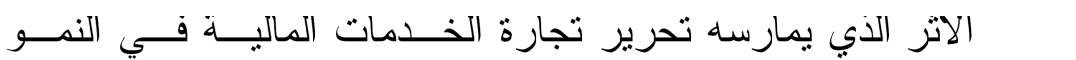

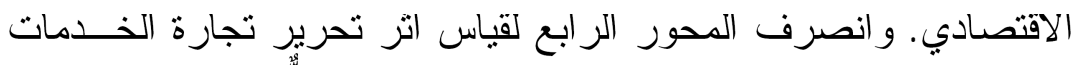

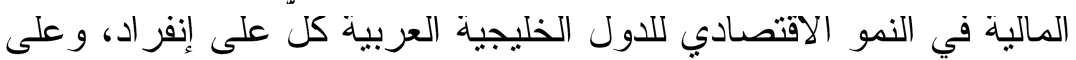
مستوى مجلس التعاون لدول الخليج العربية مجتمعة للمدّة (1991-2007).

\section{المحور الاول: - مفهوم تجارة الخدمات الماليه وتحريرها والياتها}


ينصرف المفهوم الاصطلاحي لتجارة الخدمات المالية بحسب التعريف الدي اوردته الاتقاقية العامة للتجارة في الخدمات (GATS) إلى "الخدمات

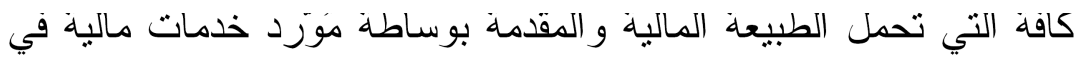

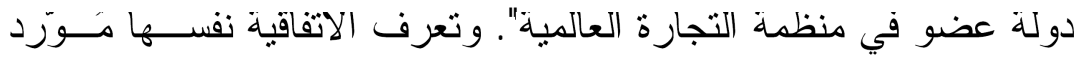

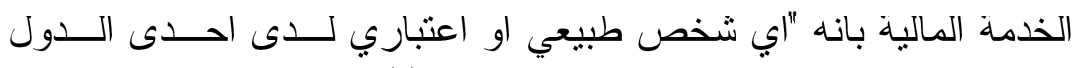

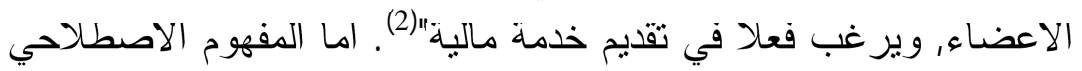

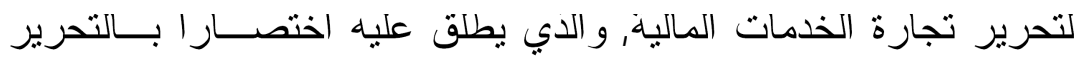

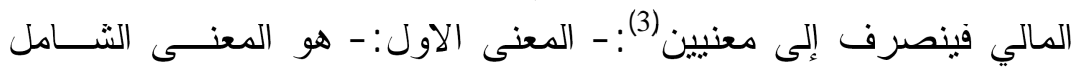

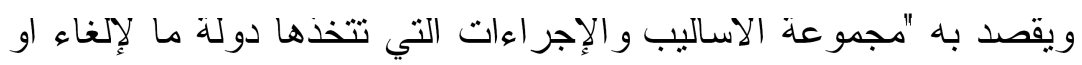

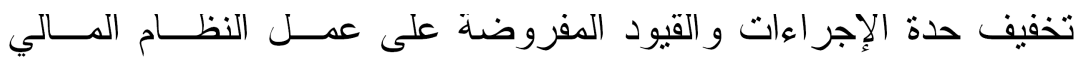
و المصرفي وذلك بقصد تعزيز مستوى كفاءته و إصـلاحه كليا'. و المعنـى الإنى

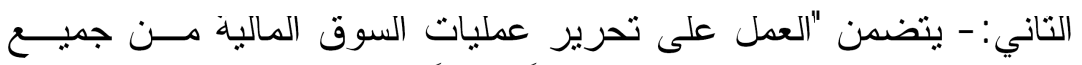

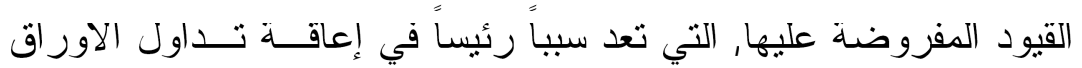
المالية على المستويين المحلي و الدولي".

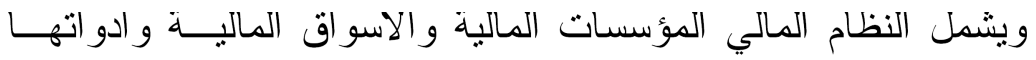

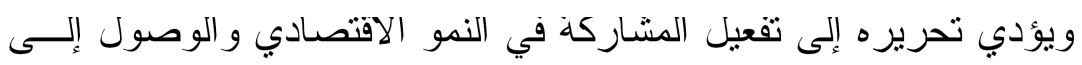

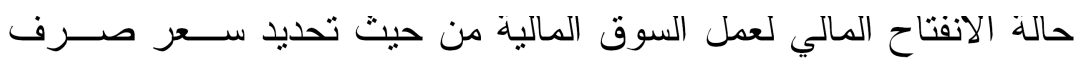

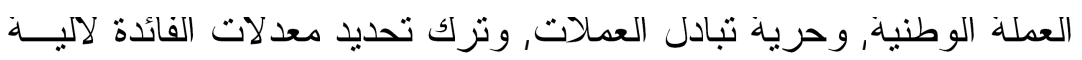

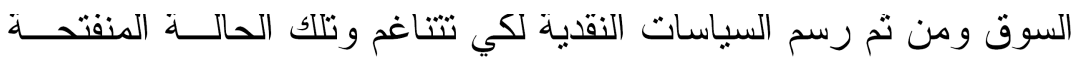

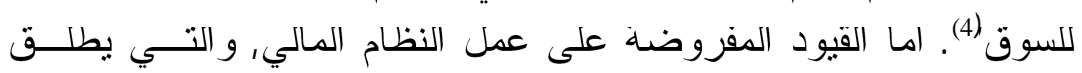

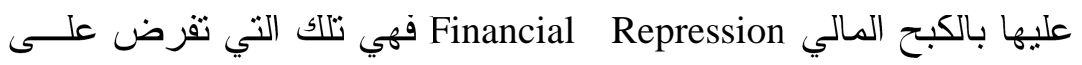
المنافسة في الاسواق المالية, وتتمثل بالئشكل الاتية(5): - القيود المفروضة على رؤوس الامو ال المتدفقة من الخارج إلى الداخل ونل الدهل او بالعكس.

- القيود المفروضة على المنافسة الاجنبية في الاسواق المالية المحلية. 
- العمل على ضمان حد ادنى من هامش الوساطة المالية, وذلك من خلال

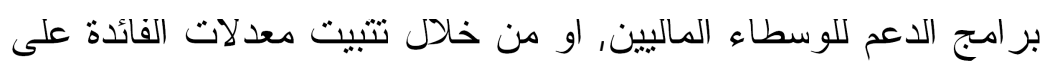

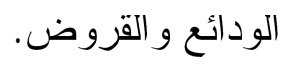

- العمل على فرض قيود على عملية خروج الوسطاء الماليين من السوق التي غالباً ما تكون مصحوبة بعمليات تامين غير محددة للودائع. - العمل على نامين القروض الاساسية في محافظ الائنمان المصرفي.

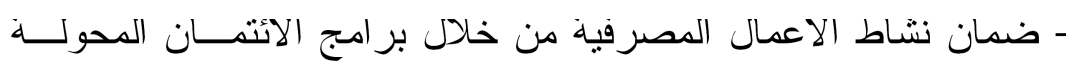
حكومياً للقطاعات الرئيسة.

اليات تحرير الخدمات الماليه: - تتمل بالآثي (6): - إلغاء ضو ابط الصرف: - يجري ذلك عن طريق اعتماد سعر صــرف

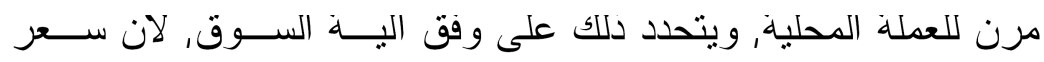

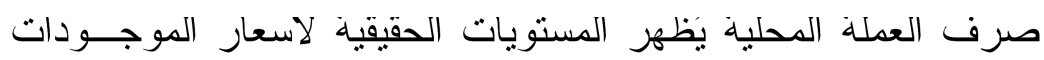
المحلية، وقد تم اعتماد هذا الإجراء فـي اغلــب الــدول الر اســــالية المتقدمة.

- تحرير معاملات راس المال: - إناحة الحرية لانتقل رؤوس الامــوال من و الى النشاطات الاقتصـادية المختلفة و الذي يؤدي بدوره إلى إمكانية امتلاكك المقيمين للاصول المالية و النقدية و المادية الاجنبية وكذا الحـــال فيما يخص الاجانب غير المقيمين في امتلاك الاصول المحلية وتداولها. ومن الجدير بالذكر، ان عملية تحرير معاملات حسـاب راس المـــال

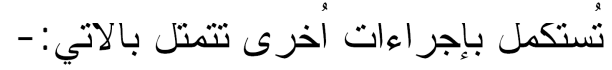

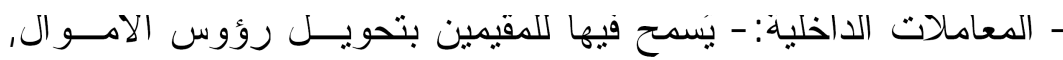

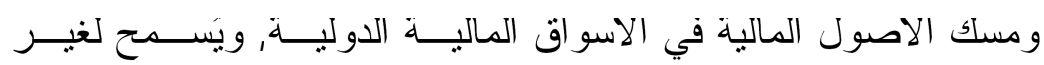
المقيمين إصدار المطلوبات و الاقتر اض من الاسو اق المحلية. 
- المعاملات المحلية بالعملات الاجنبيــة: - يَســمح فيهــا للمقرضــين

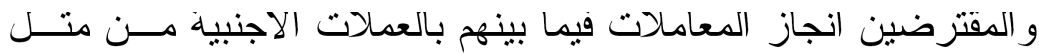

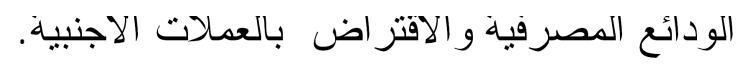

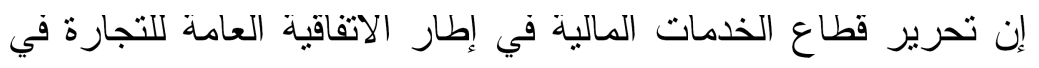
الخدمات, تم الاتفاق عليه بين الدول الاعضاء في منظمة التجارة العالمية

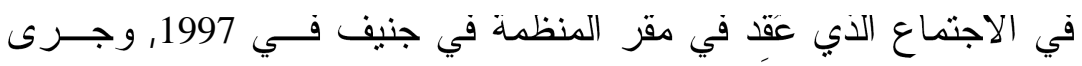
الاتفاق على إز الة القيود الدولية المفروضة على نشاط المؤسسات المالية

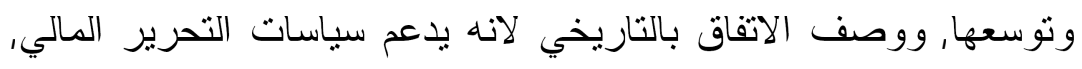

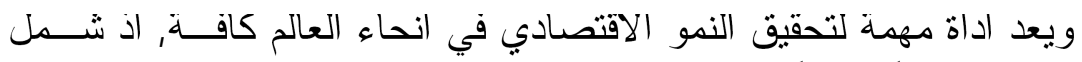

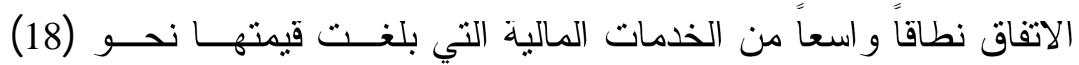

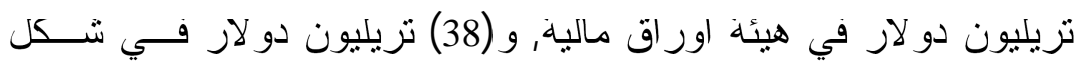

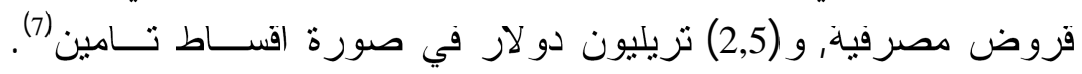

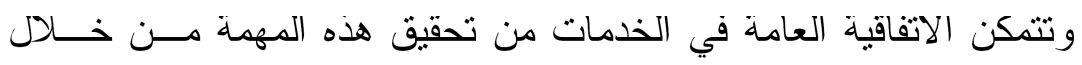
مبادئها و احكامها التي تتص عليها, وتحظر بموجبها على الدول الاعضهاء

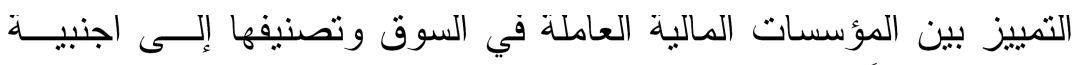

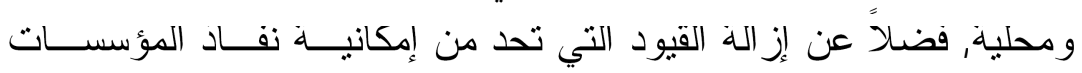

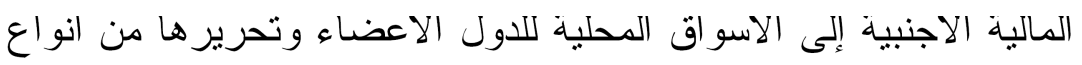

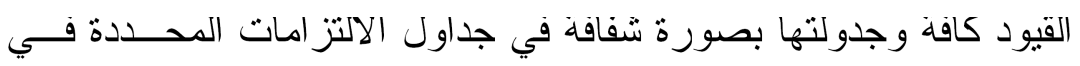
حالة و جودها. 
قبل البدء في إدراج مزيات تحرير تجارة الخدمات الماليــة وســلبياته

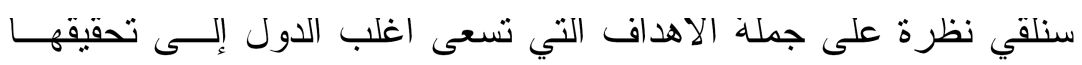

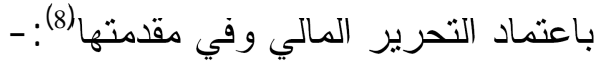

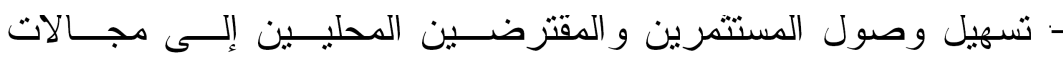
الاستتمار ومصادر التمويل الدولية, وبالمقابل تسهيل دخول الثــركات و المستثمرين الاجانب إلى الاسو اق المالية المحلية.

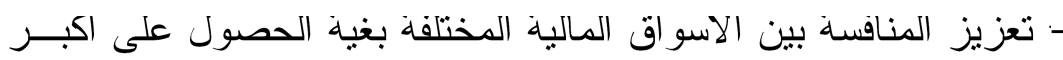

$$
\text { قدر ممكن من رؤوس الامو ال الدولية. }
$$

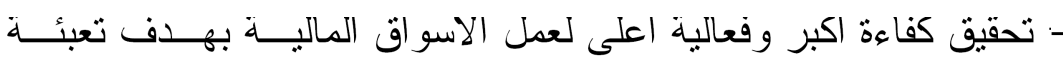
الادخار ات المحلية و الاستفادة منها في عمليات التمويل.

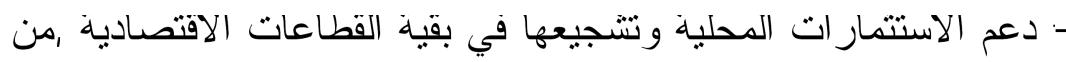
خلال تامين رؤوس الامو ال عبر مصادر ها المختلفة(9).

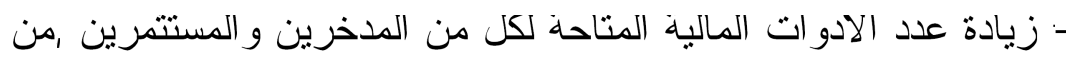
خلال توسيع البنية التحنية المالية, وتحسين الإطار العام لعملية الوساطة

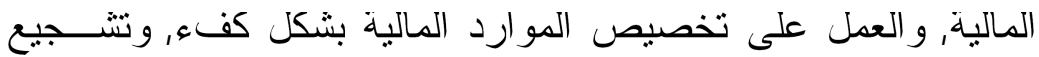
الإدخار ات, وزيادة عرض الائتمان الكلي للقطاع المصرفي (10).

بعد التعرف على اهم الاهداف التي تسعى الدول إلى تحقيقها من جراء

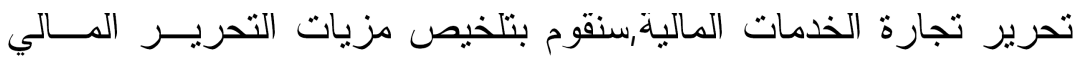
وسلبياته.

مزيات تحرير تجارة الخدمات الماليه: - يمكن حصر اهم مزيات التحرير

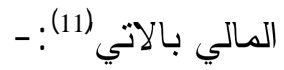


[59]

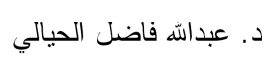
لانضمام إلى منظمة التجارة العالمية

1. العمل على تحريك المصادر المالية من دول الفائض في راس المــال

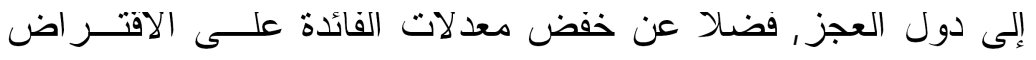
وبخاصـة تجاه القطاعات الاقتصادية الر ائدة: الصــناعية و الزر اعيــة الزهة

$$
\text { و والتجارية. }
$$

2. تعزيز المنافسة في الاسواق المالية، وتحسين كفاءة إدارة الخدمات التي

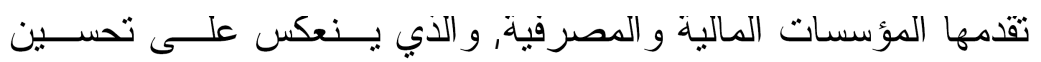

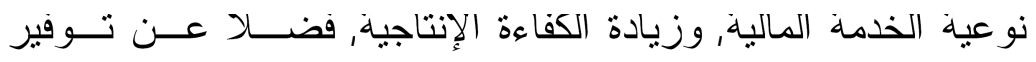
خيار ات افضل للمستهلكين.

3. الإسهام في تحســين الاداء الاقتصـــادي علــى مســتوى المتغيـر ات

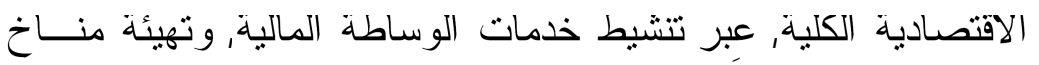
ملائم يزيد الفرص الاستتمارية، من خلال تخصيص افضل للمـــوارد بين القطاعات الاقتصادية وبين الدول المختلفة.

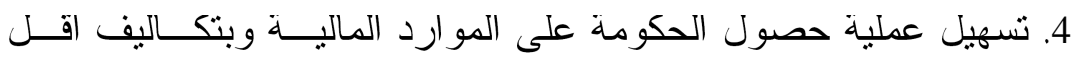

لتمويل قطاعاتها الاقتصادياة, فضدل عن حفز الحكومة لتحسـيـين إدارة السياسات الاقتصادية الكلية، وسياسات الإشر اف و الرقابة على القطاع

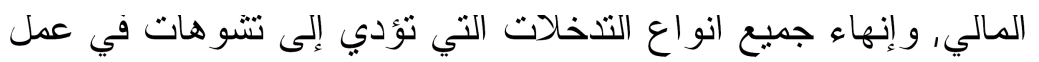

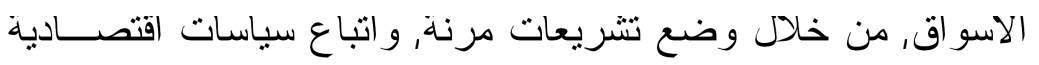

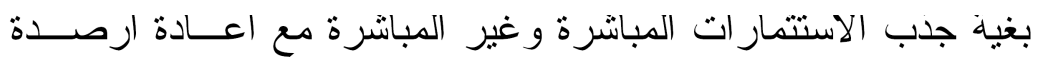

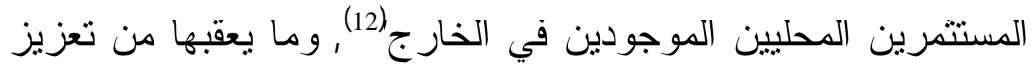
امكانية حصول المستتمر المحلي على القروض وخدمتها باقل تكاليف ممكنة, ناهيك عن تحسين نوعية التدفقات النقدية, بما يؤدي إلــى ردم فجوة الادخار ات التي تعاني منها اغلب الدول النامية(13.

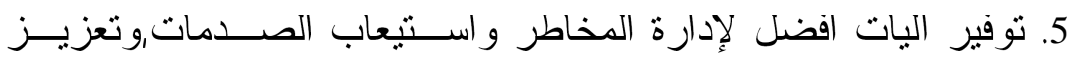

الفرص الاستتمارية من خلال التوزيع القطاعي الفعال للمو ارد(14). 
6. السعي من اجل التخلص من القيود المالية من مثل الحد الاعلى لمعدل

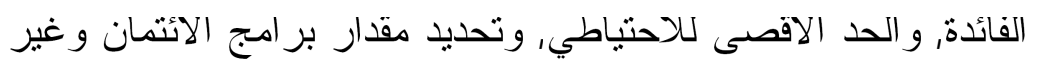

دلك من المحددات التي تشكل الإطار القانوني لعمل الاسواق الماليـــة

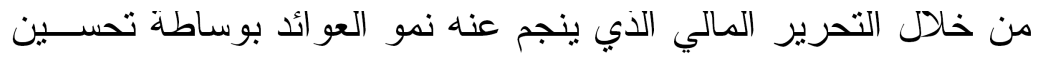

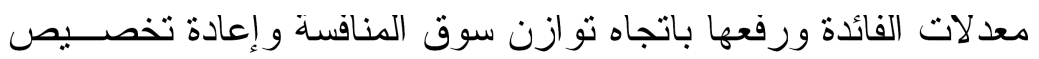

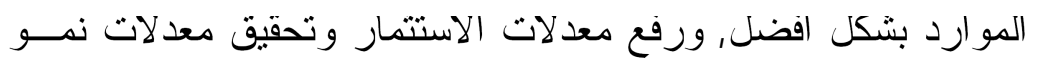
اقتصادي في الاجل الطويل(15).

7. استـناء الاختلال الحاصل في الاسواق المالية، و العمـلـل علــى حفــز

تاثير ات مضادة على بنية راس المال وتدققه, وبذلك تعد عملية التحرير

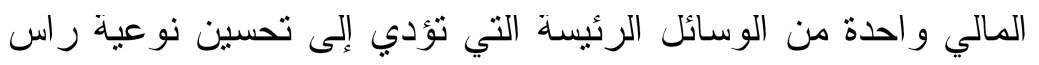
المال المتدفقر ومن ثم تقوية النظم المالية (16).

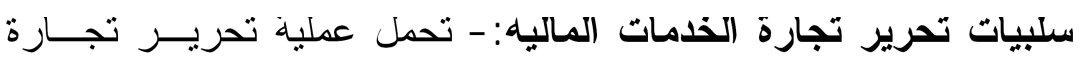

الخدمات المالية في صلبها سلبيات عدة يمكن ثلخيصها بالاتي (17): -

1. تؤدي إلى تهميش المؤسسات المالية المحلية لعدم قدرتها على المنافسة,

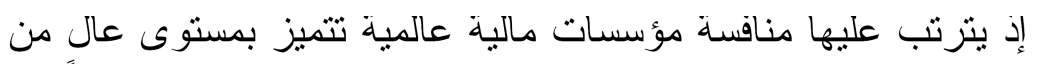

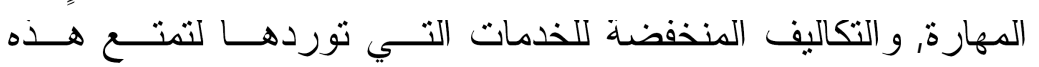

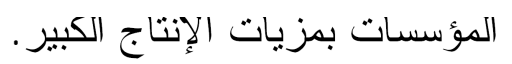

2. تقوض استقرار النظام المالي ومن نم الاقتصـاد الكلي, إد تــؤتز ســلبا

وبطريقة غير مباشرة في الاستقر ار المالي وذلك عن طريــق زيــــادة

قابلية تدفقات ر اس المال للتقلب.

3. سيطرة المؤسسات المالية الاجنبية على الاسواق المالية المحلية، و عادة

ما يكون الموردون الاجانب اكثر كفاعة من نظر ائهم المحليين.

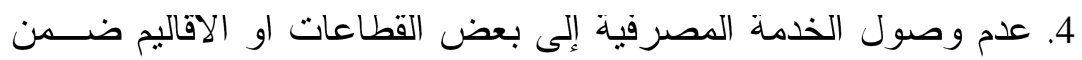

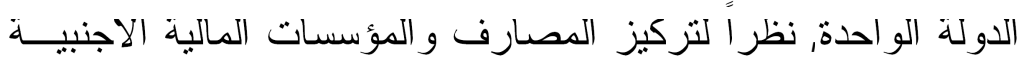


[61]

على خدمة القطاعات الاقتصادية المربحة من السوق و التي يشار إليها

$$
\text { بالاختيار الافضل. }
$$

5. إن التحرير المالي يعني الاندماج في النظام المالي العالمي و المشاركة

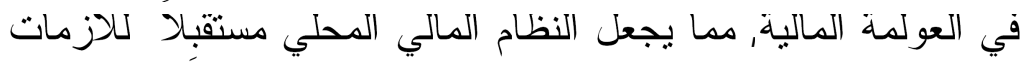

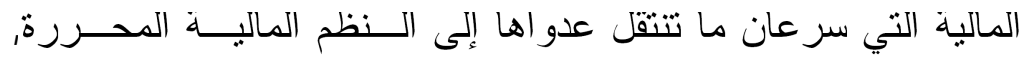

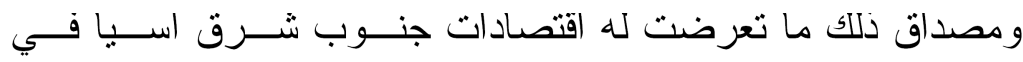

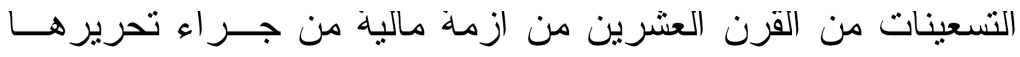
المالي غير المنضبط.

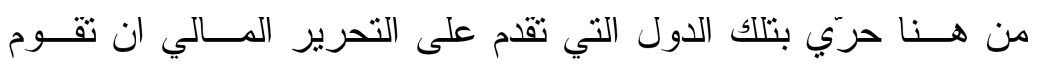

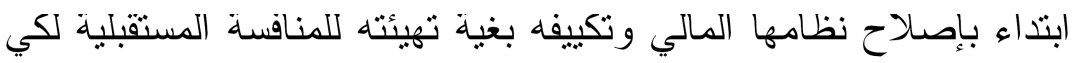
يتمكن من التنافس بشكل فعال على المستوى الدولي.

المحور التالت: - الدراسات السابفه التي تتاولت تحرير تجارة الخدمات الماليه وعلافتها بالنمو الاقتصادي

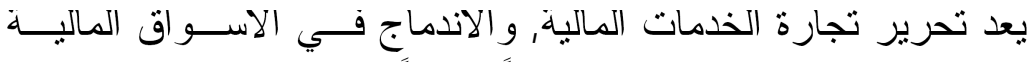

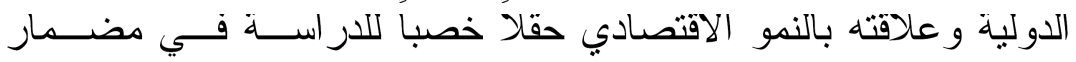

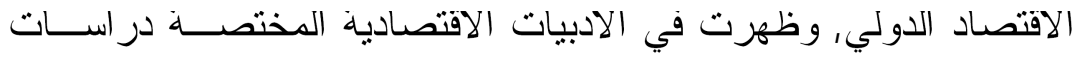
مكتفة تتاولت تحليل الاتر الدي تمارسه عملية تحرير تجــارة الخــدمات

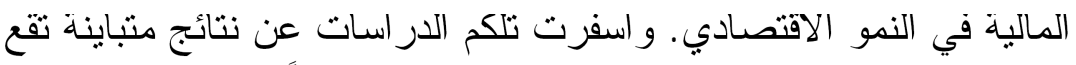

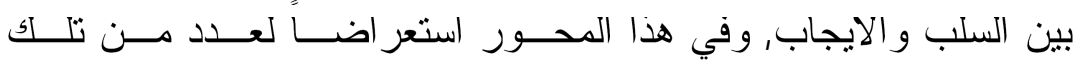

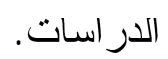
1. بينت در اسة (Dobson \& Jaquet, 1998) ان تحرير القطــــاع المــالي

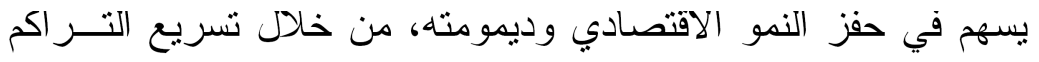

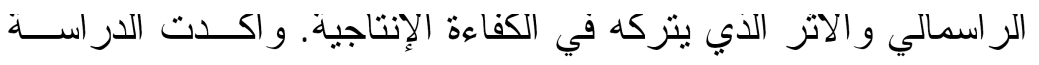


ضرورة ان ير افق عملية التحرير المالي تطوير القطاع المالي للحؤول دون وقو عه في الازمات المالية(18).

2. اظهرت در اسة (Francois \& Shknecht, 1999) وجود علاقة ارنباط

قوية بين الانفتاح (التحرير) المالي ودرجة المنافسة و النمو الاقتصادي،

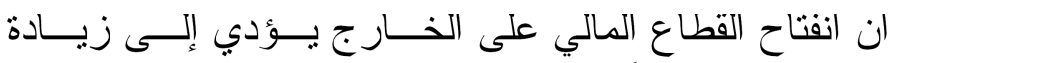
المنافسة التي تتعكس ايجابياً على النمو الاقتصادي) (19).

3. وكدت الدر اسة التي اعدها (US Council For International Business) إن تحرير تجارة الخدمات المالية دو اتر ايجابي في النمو الاقتصادي,

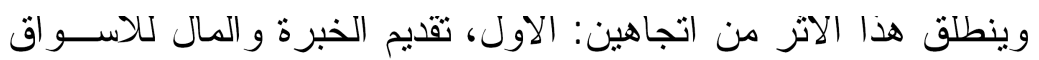
المحلية النامية، وتشجيع الادخار المحلي، وزيادة الاستتمار ات المحلية

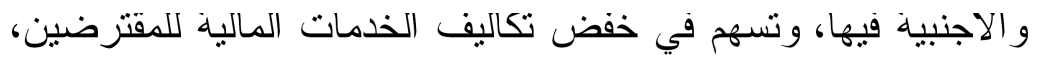
ومن ثم تحقيق الكفاءة الاقتصادية في استخدام راس المال ورفع معدل

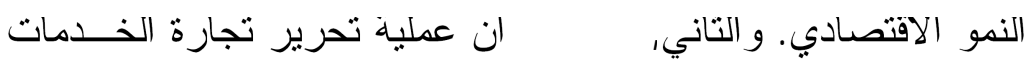
المالية تؤدي إلى توليد اتار ايجابية قي القطاعات الاقتصـادية و انعكاس ذلك على النمو الاقتصادي(20).

4. خلصت در اسة (Achy, 2003) لعينة من الدول النامية إلى ان عمليــة التحرير المالي التي تتمثل بتحرير معدلات الفائدة, وتخفيض احتياجات

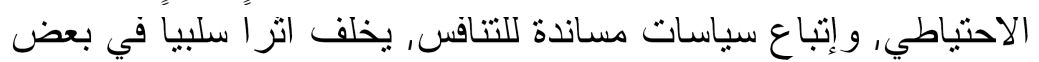

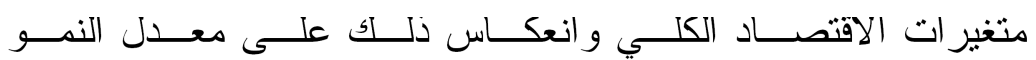
الاقتصادي) (21).

5. خرجت در اسة (Clickman \& Arestis, 2003) بنتيجة فحو اها ان ثمــة

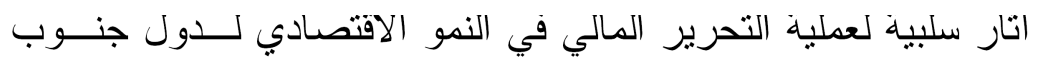

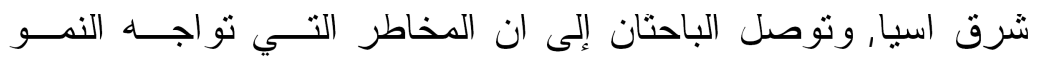
الاقتصادي الناجمة عن وجود قطاع مالي غير مستقر تتضـاعف فـي لـي 
الاقتصادات النامية المتحررة, عندما يكون التحرير المالي عاملا مهما

$$
\text { في هده العملية (22). }
$$

6. استعرضت در اسة (Canar \& Arestis, 2004) الطر ائق المختلفة التـي

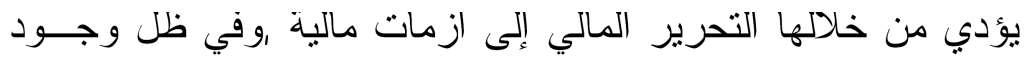

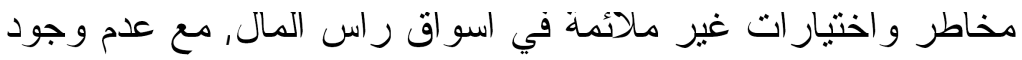

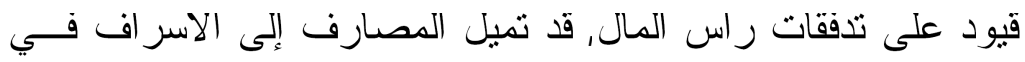

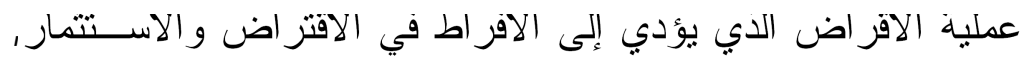

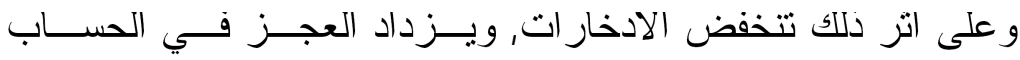

الجاري, الذي يضع القطاع المصرفي في مشكلة خطبرة,مما بــؤدي

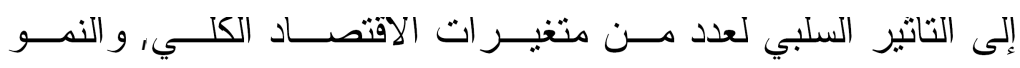

الاقتصادي (23).

7. اتبتت در اسة (الاغا، 2004) وجود علاقة ايجابية بين التغيـرات فـي التيكي

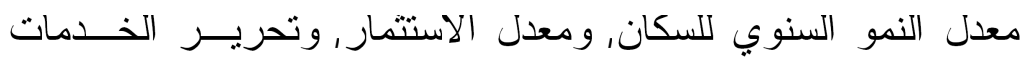

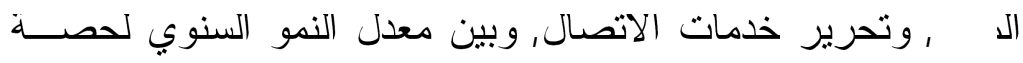

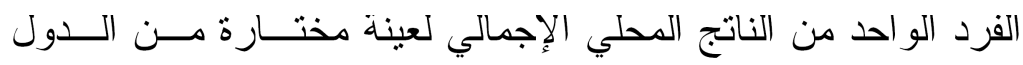
النامية للمدة (24) (2000)

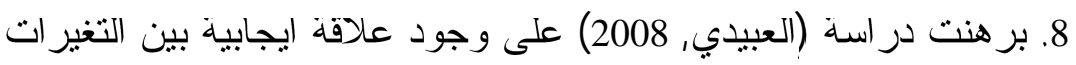

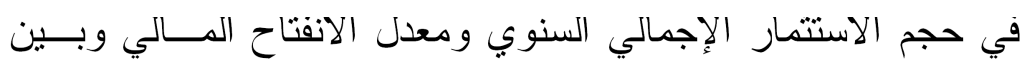

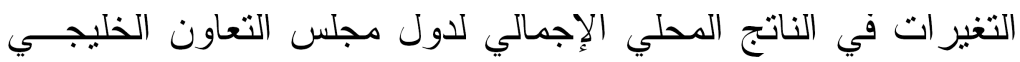
بوصفها كتلة اقتصادية واحدة.في حين كانت العلاقة سلبية بين معدل

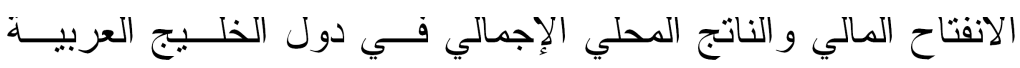
باسنتناء البحرين للمدة( (2091 -2005)

المحور الرابع: - وياس اتر تحرير تجارة الخدمات الماليه وي النمو

الإقتصادي وتحليله للاول الخليجيه العربيه للمدة (1991-2007) 
تم استخدام بيانات سنوية عن حجم الناتج المحلي الإجمالي للول العينة

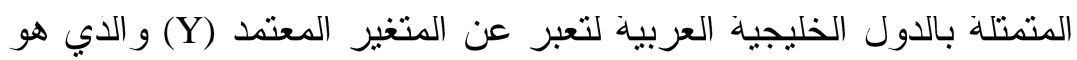

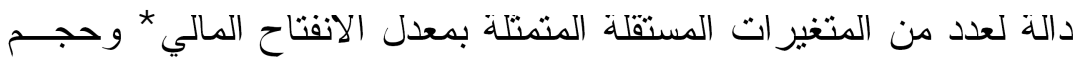
الاستتمار الإجمالي فضلاً عن حجم الاستهالك النهائي وصافي التجـــارة

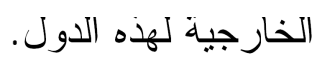

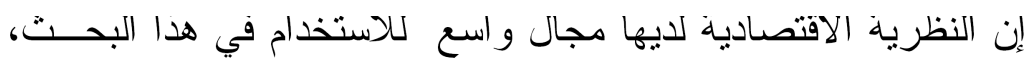
كذلك سيعتمد التحليل على المنطق الاقتصادي لتبيان طبيعة العلاقة بــين

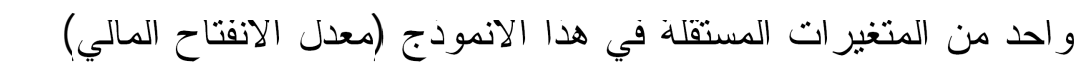
المتغير التابع (حجم الناتج المحلي الإجمالي). يشير المنطق الاقتصادي إلى وجود علاقة طردية بين الناتج المحلـي الإجي

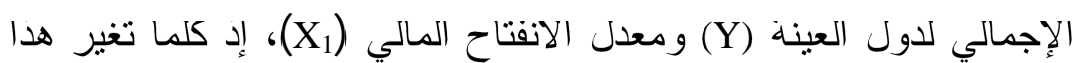

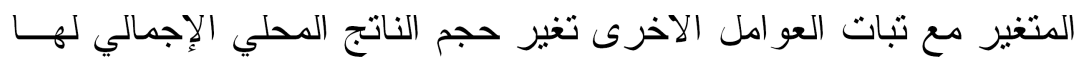

$$
Y=f\left(X_{1}\right) \ldots \ldots .(1)
$$

بشكل مقابل.

تشير النظرية الاقتصادية إلى إن العلاقة بين الناتج المحلي الإجمــالي

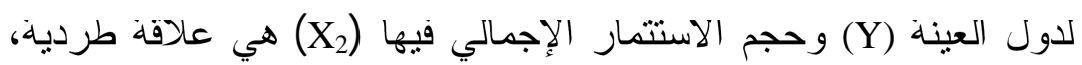

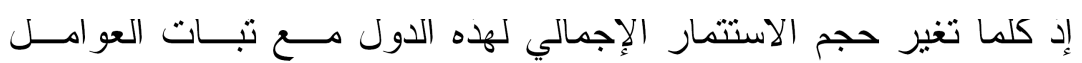
الاخرى تغير حجم الناتج المحلي الإجمالي لها بشكل مقابل.

$$
Y=f\left(X_{1}, X_{2}\right) \ldots \ldots(2)
$$

تبين النظرية الاقتصادية كذلك، إن هناك علاقة طردية بـين النــاتج المحلي الإجمالي لدول العينة (Y) وحجم الاستهلاك النهائي فيها (X3)، إذ كلما تغبر حجم الاستهلاكك النهائي في هده الــدول مــع تبـــات العو امــل الاخرى تغير حجم الناتج المحلي الإجمالي فيها بشكل مقابل. 
[65]

$$
Y=f\left(X_{1}, X_{2}, X_{3}\right) \ldots \ldots . .(
$$

تظهر النظرية الاقتصادية كذلك، إن هناك علاقة طردية بـين النــاتج

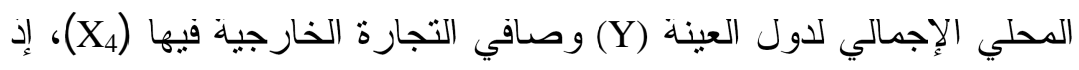

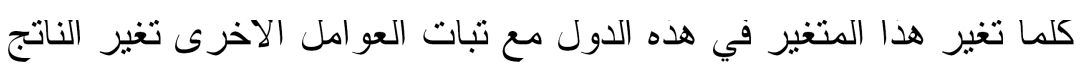
المحلي الإجمالي فيها بشكل مقابل.

$$
Y=f\left(X_{1}, X_{2}, X_{3}, X_{4}\right) \ldots \ldots . .(4)
$$

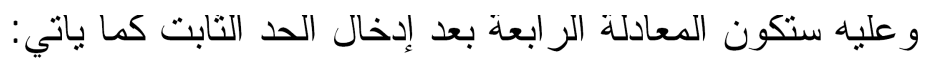

$$
Y=B_{0}+B_{1} X_{1}+B_{2} X_{2}+B_{3} X_{3}+B_{4} X_{4} \ldots . .(5)
$$

و إن النقدير ما لم يحتوِ على حد الاضطر اب (Ui) فإنه لا يعبــر عـن

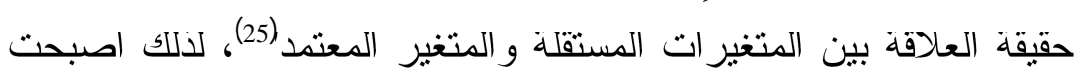
الصيغة المعبرة عن حقيقة العلاقة كالاتي: -

$$
Y=B_{0}+B_{1} X_{1}+B_{2} X_{2}+B_{3} X_{3}+B_{4} X_{4}+U_{i}
$$

تمَّ استخدام برنامجي (Minitab) و (SAS) في تقدير انموذج الانحدار

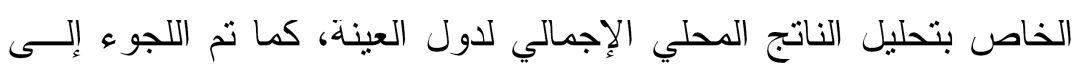
استخدام بعض التحليلات الخاصة المنتلة بتحليل البو اقي وتحليل المسار . 
إن تحليل المسار قائم على تجزئة ارنباطات الناتج المحلي الإجمــالي (الذي يمثل المتغير التابع او المعتمد) إلى تاثيرات مباشرة وغير مباشرة،

وبالطريقة التي ذكرت من لدن كل من البــاحثين (1959) Dewey\& Lu . كما تمت الاستعانة بتصنيف قيم التاثير ات المباشرة وغير المباشرة فـي إني

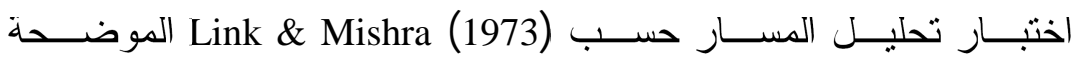
كالآتي (27): -

الجدول (1): تصنيف فيم التاتيرات المباتُرة وعير المباترة وي إختبار تحليل

\begin{tabular}{|c|c|c|c|c|c|}
\hline \multicolumn{6}{|c|}{ المسار } \\
\hline 1.00 & $\begin{array}{c}0.99- \\
0.30\end{array}$ & $\begin{array}{c}0.29- \\
0.20\end{array}$ & $\begin{array}{l}0.19- \\
0.10\end{array}$ & $0.09-0$ & التأثير اتي \\
\hline & & & قليل & يهمل & تصنيفها \\
\hline
\end{tabular}

تقدير داله الناتج المحلي الإجمالي في دوله الإمارات العربيه المتحدة للمدة (2007-1991)

للحصول على افضل توفيق للانموذج فقد تمت الاستعانة بــالانموذج

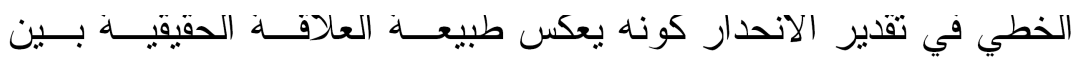
المتغير ات المسنقلة و المتغير التابع المستخدمين في هدا التحليل. لهديل. $Y=-13752+2.1994 X_{2}+1.1190 X_{3}$ (4.82) (3.21) (4.66)

الجدول (2): تقدير داله التاتج المحلي الإجمالي لاوله الإمارات العربيه المتحدة للمدة (2007-1991)

\begin{tabular}{|l|l|}
\hline أسماء المتغيرات & المتغير ات \\
\hline
\end{tabular}




\begin{tabular}{|c|c|c|c|c|c|}
\hline & & & ) & صافم الاستهلاك الن & $\begin{array}{r}\mathrm{Y} \\
\mathrm{X} 1 \\
\mathrm{X} 2 \\
\mathrm{X} 3 \\
\mathrm{X} 4\end{array}$ \\
\hline & & $(\mathrm{t})$ & الحرية & & \\
\hline Constant & -13752 & 4.82 & 2 & $=99.1 \% R^{2}$ & \multirow{4}{*}{$\mathrm{X} 3 \quad 0.980$} \\
\hline$X_{2}$ & 2.1994 & 3.21 & 14 & $R^{-2}=99.0 \%$ & \\
\hline \multirow[t]{2}{*}{$X_{3}$} & 1.1190 & 4.66 & 16 & $F=788.69$ & \\
\hline & & & & $D W=1.14$ & \\
\hline
\end{tabular}

المصدر: الجدول من إعداد الباحث بالاعتماد على مخرجات الحاسبخ الاكترونية.

إن المتغيرين المستقلين المستخدمين في هذا الانموذج اجتاز ا اختبــار

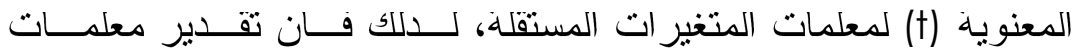

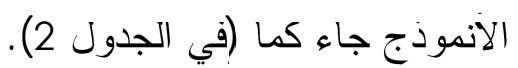

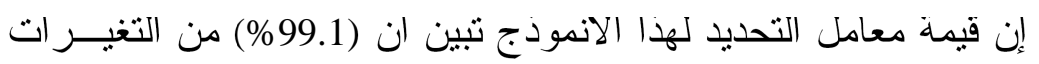

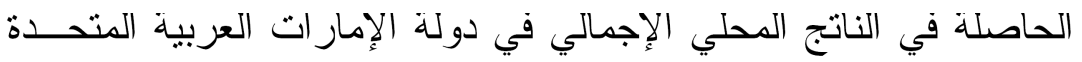

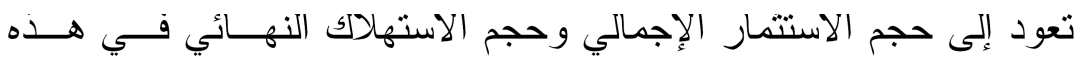

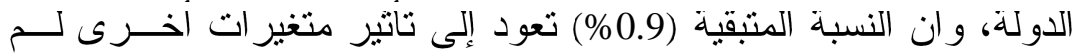
تلخل ضمن هذا الانمودج تسمى عادة بالمتغبر العشو ائي. تبين قيمة اختبار (F) معنوية الانموذج عند مسنوى معنويــة (0.05)

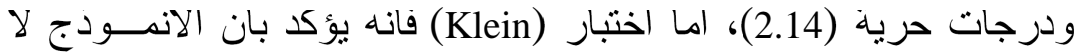
يعاني من مشكلة الارنباط الخطي بين المتغير ات المستقلة،لكن قيمة اختبار

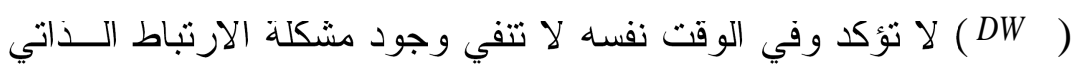
في الانمودج إد ان القيمة المحتسبة لهدا الاختبار و اقعة في منطقة عــدم التوكد الموجبة. 
إن نتائج التقدير لهذا الانموذج تبين ان هناك علاقة طردية ذات ناثير

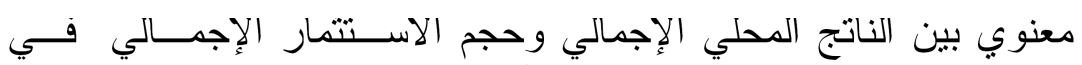

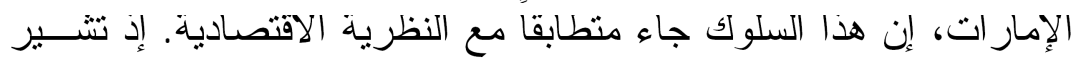

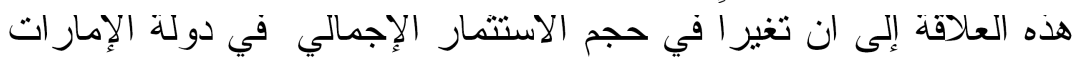
بمقدار وحدة و احدة مع ثبات العو امل الاخرى، سيؤدي إلى تغير مقابل في الإني الناتج المحلي الإجمالي بمقدار (2.1994) وحدة. إن التاثير المعنوي الاكبر في الناتج المحلي الإجمالي للإمار ات يعــود الإده

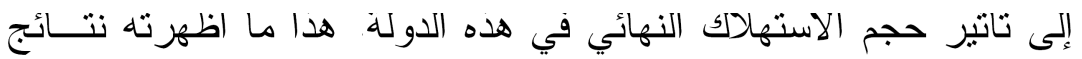
التقدير لهذا الانموذج التي تبين بان هناك علاقة طردية ذات تاثير معنوي

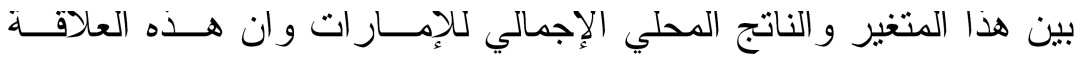
جاءت منطابقة مع المنطق الاقتصادي. إذ تعني هذه العلاقة إن تغير أ في

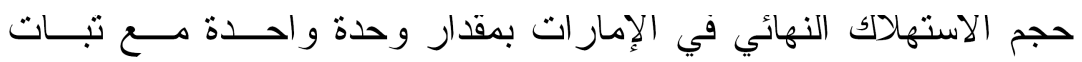

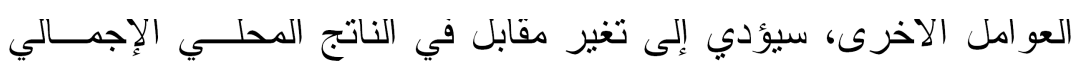
للإمار ات بمقدار (1190) وحدة.

\section{تحليل المسار في دوله الإمارات العربيه المتحدة:}

لقد تم اعتماد قيم معاملات الارتباط المبينذة في مصفوفة الارنباط ضمن

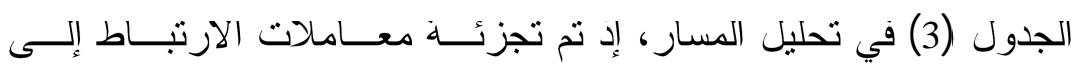

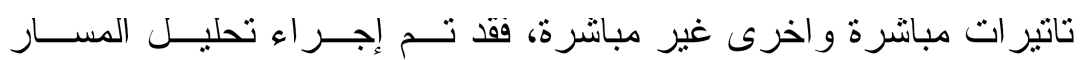

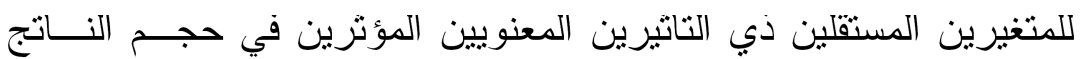
المحلي الإجمالي في دولنة الإمار ات وكما هو موضح في الجدول الاتي: 


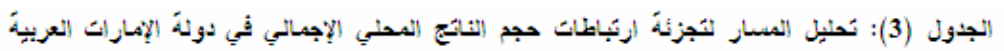

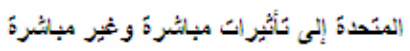

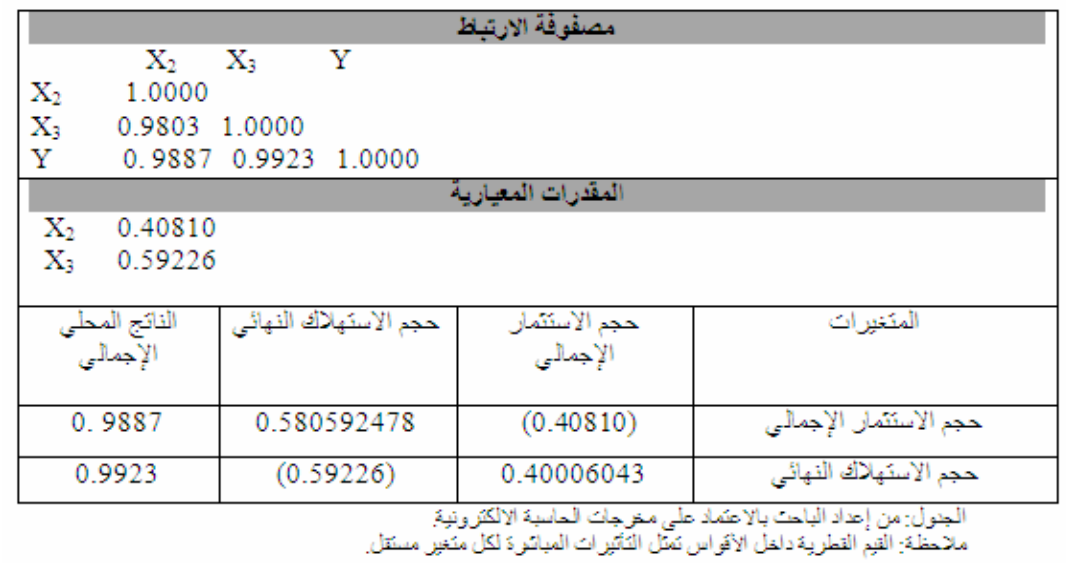

من الجدول (3) الذي يمتّل تحليل المسار لتجزئة ارتباطــات النــاتج

المحلي الإجمالي في دولة الإمار ات العربية المتحدة إلى ناثير ات مباثـــرة

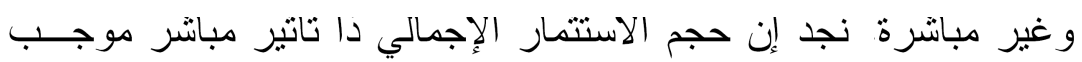
و عالٍ في الناتج المحلي الإجمالي، في حين تظهر نتائج القياس إن التاثير

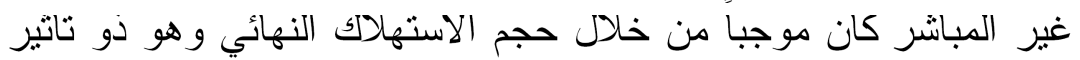
علل.

و على وفق النتيجة السابقة وفيما يخص التاتير ات المباشرة، فقد كــان

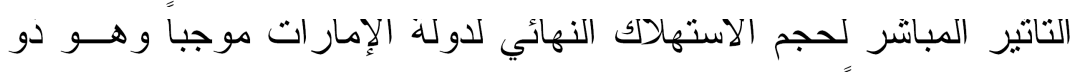

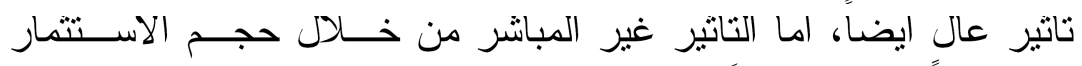

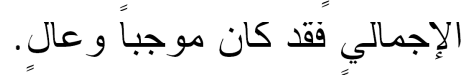

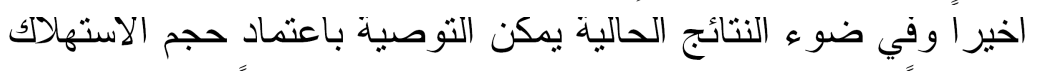

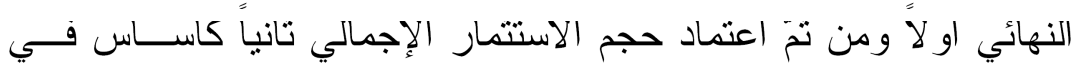


در اسات إقليمية 6 (18)

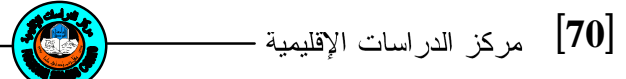

تحديد العو امل المؤثرة في الناتج المحلي الإجمالي لدولة الإمار ات العربية المتحدة.

تقدير داله الناتج المحلي الإجمالي لمملكه البحرين للمدة (1991-2007) للحصول على افضل توفيق للانموذج فقد تمث الاستعانة بــالانموذج الخطّي في تقدير الانحدار كونه بعكس طبيعــة العلاقــة الحقيقبــة بــين المتغير ات المستقلة و المتغير التابع المستخدمين في هذا التحليل. إن المتغير ات المستقلة الثلاثة المستخدمة في هدا الانمــودج اجتــازت جمبعا اختبار المعنوية (t) لمعلمات المتغير ات المستقلة، لذلك فان تقـدير معلمات الانمودج جاء كما باتي:

$\mathrm{y}=-282.4+0.993 \times 2+1.07 \times 3+0.823 \times 4$ $(-0.30) \quad(5.42) \quad(4.08) \quad(4.17)$

الجدول (4): تقدير داله الناتج المحلي الإجمالي لمملكه البحرين للمدة (1991-2007)

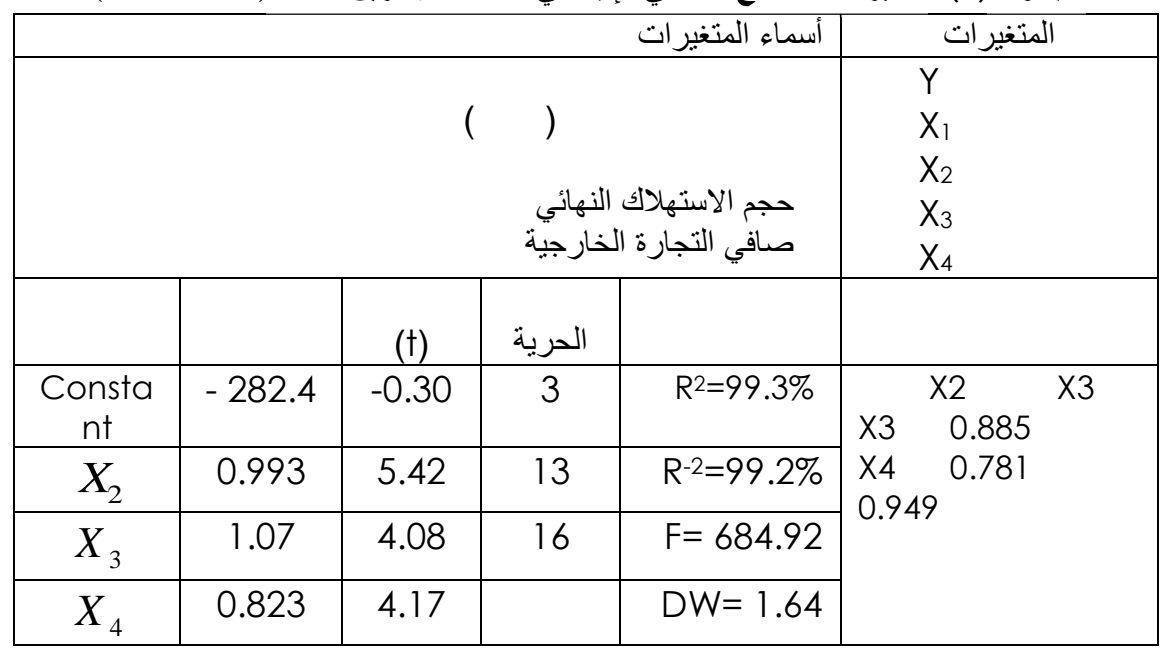

المصدر: الجدول من إعداد الباحث بالاعتماد على مخرجات الحاسبة الالكترونية. 
إن قيمة معامل التحديد لهذا الانموذج تبين ان (99.3) من التغيرات

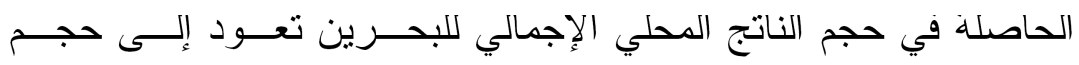

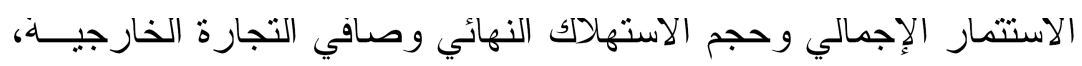

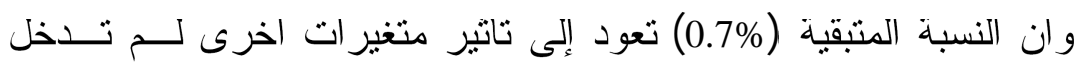
ضمن هذا الانمودج تسمى عادة بالمنغير العشو ائي.

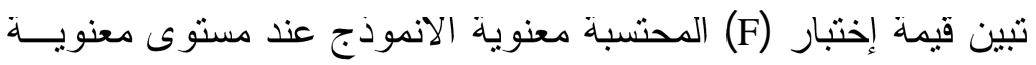

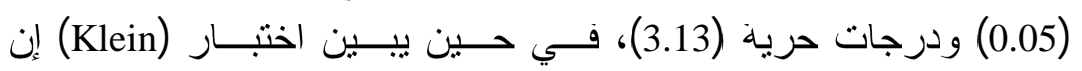
الانمودج لا يعاني من مشكلة الارتباط الخطي بين المتغير ات المســـقلقلة. و ان قيمة اختبار (DW) المحتسبة تؤكد عدم وجود مشكلة الارنباط الذاتي لئي

$$
\text { بين قيم المتغير العشوائي. }
$$

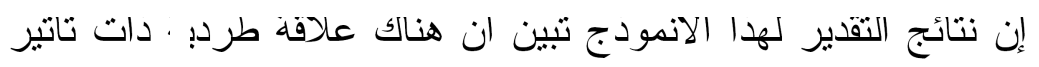

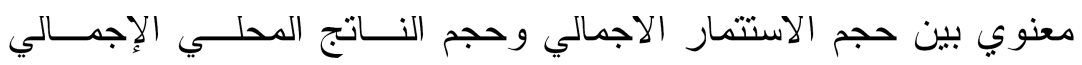

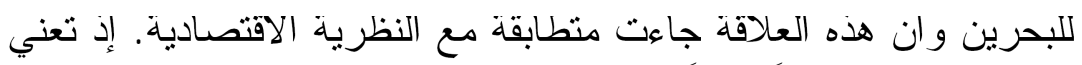

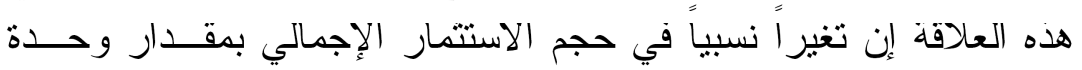
و احدة مع تبات العو امل الاخرى، سيؤدي إلى تغير نسبي مقابل في الناتج

$$
\text { المحلي الإجمالي لها بمقدار (0.993) وحدة. }
$$

يعود التاتير المعنوي الاخر في حجم الناتج المحلي الإجمالي للبحرين

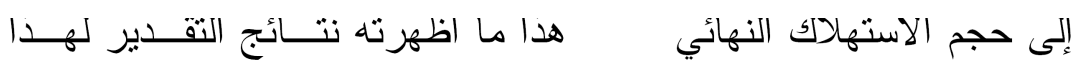

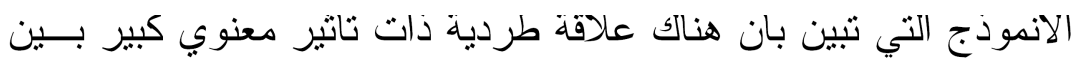

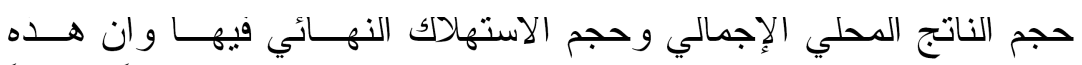
العلاقة كانت متطابقة مع النظرية الاقتصادية، فهي تعني إن تغير اً نســبياً

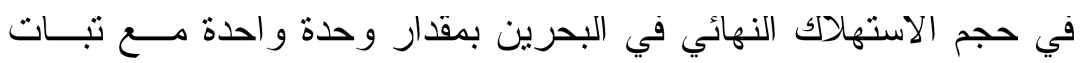
العو امل الاخرى, سيؤدي إلى تغير نسبي مقابل في حجم الناتج المحلـي لئي الإجمالي بمقار (1.07) وحدة. 
تبين نتائج التقدير لهذا الانموذج إن هناك علاقة طرديــة ذات تــاتير

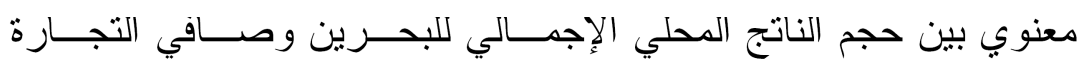

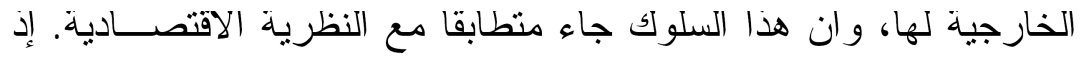
تشير هده العلاقة إلى ان تغيراً نسبياً في صافي التجارة الخارجية للبحرين

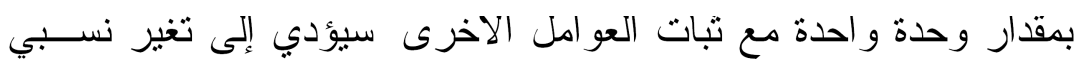
مقابل في حجم الناتج المحلي الإجمالي بمقدار (0.823) وحدة.

\section{تحليل المسار في مملكه البحرين: -}

لقد تم اعتماد قيم معاملات الارتباط المبينة في مصفوفة الارتباط ضمن الجدول (5) في تحليل المسار ، إد تم تجزئة معاملات الارنباط إلى تاتيرات

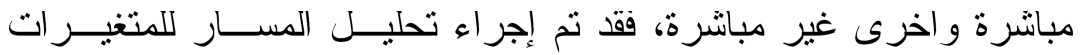

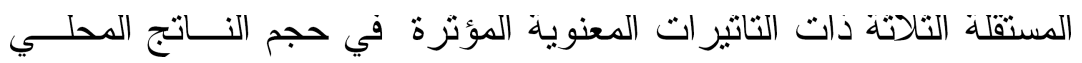
الإجمالي في مملكة البحرين وكما هو موضح في الجدول الاتي:

\begin{tabular}{|c|c|c|c|c|}
\hline \multicolumn{5}{|c|}{ مصفوفة الوزتبط } \\
\hline $\begin{array}{ll} & \mathrm{X}_{2} \\
\mathrm{X}_{2} & 1.0000 \\
\mathrm{X}_{3} & 0.8848 \\
\mathrm{X}_{4} & 0.7811 \\
\mathrm{Y} & 0.9172\end{array}$ & $\begin{array}{lc}\mathrm{X}_{3} & \mathrm{X}_{4} \\
& \\
.0000 & \\
0.9488 & 1.0000 \\
0.9879 & 0.9530\end{array}$ & 1.0000 & & \\
\hline $\begin{array}{ll}\mathrm{X}_{2} & 0.28632 \\
\mathrm{X}_{3} & 0.42608 \\
\mathrm{X}_{4} & 0.32512 \\
\end{array}$ & & ئز بـ الثبيازية & & \\
\hline النائج الثطبي & صلفي لتجازمة & حجم الانسئهلك & 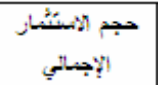 & النئنيرت \\
\hline 0.9172 & 0.253951232 & 0.376995584 & $(0.28632)$ & حجت الاستشان الإجسلمي \\
\hline 0.9879 & 0.308473856 & $(0.42608)$ & 0.253335936 & حجم الاسئهالك النهائي \\
\hline 0.9530 & $(0.32512)$ & 0.404264704 & 0.223644552 & صنالقي احجزلزة الذازجية \\
\hline
\end{tabular}


[73]

د. د. عبداله فاضل الحيالي

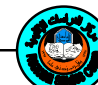
لانضمام إلى منظمة التجارة العالمية ـ

من الجدول (5) الذي يمثل تحليل المسار لتجزئـــة ارتباطـــات النـــاتج

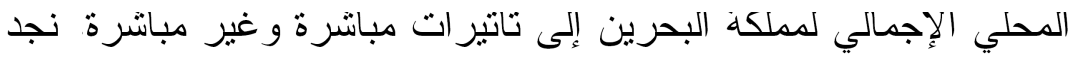

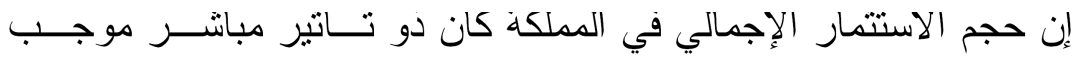
ومنوسط في الناتج المحلي الإجمالي في هده الدولة، في حين نشبر نتائج القياس إلى إن التاتير غير المباشر كان موجبا من خلال حجم الاستهلاكك

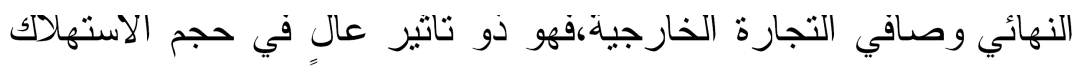
النهائي لكنه كان ذو تناثير منوسط مع صافي التجارة الخارجية.

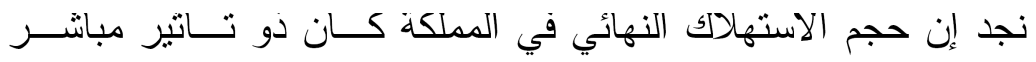
موجب و عالٍ في الناتج المحلي الإجمالي في هده الدولة، في حين تظهــر نتائج القياس إن التاثير غير المباشر كان موجباً من خلال حجم الإستثمار

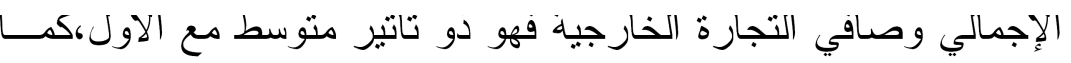
انه ذو تاثير عال مع المتغير التاني.

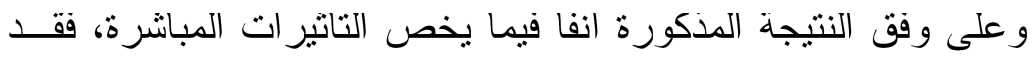

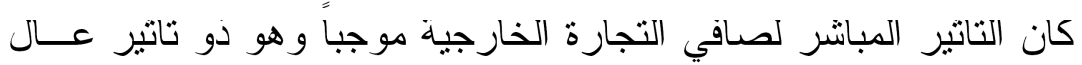

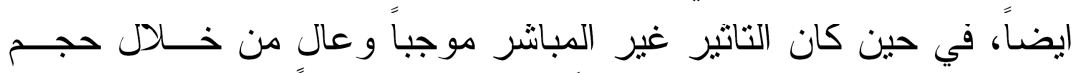

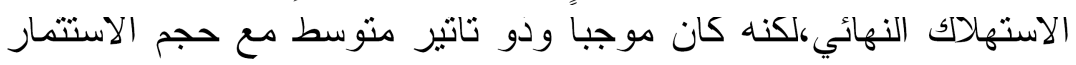
اخيراً وفي ضوء النتائج الحالية يمكن التوصية باعتماد حجم الاستهلاكك

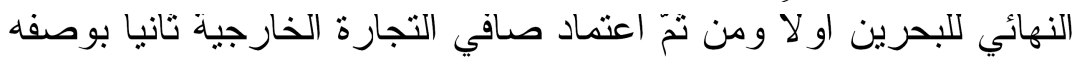

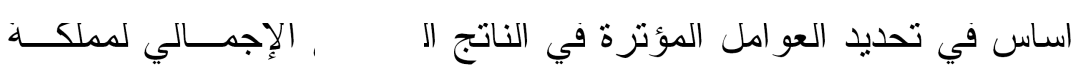
البحرين. 
تقدير داله الناتج المحلي الإجمالي المملكه العربيه السعوديه للمدة -2007)

للحصول على افضل توفيق للانمودج فقد تمت الاستعانة بــالانمودج

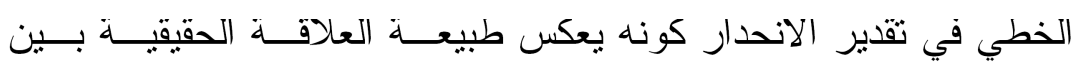

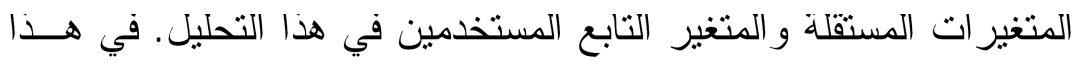

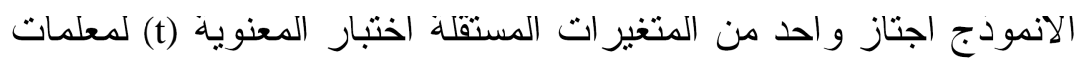

المتغير ات المستقلة، لذلك فان تقدير الانموذج جاء كما باتي: -

$Y=977228+2.3775 X_{4}$

(10.57)

الجدول (6): تقدير داله التاتج المحلي الإجمالي للمملكه العربيه السعوديه للمدة

(2007-1991)

\begin{tabular}{|c|c|c|c|c|c|}
\hline \multicolumn{5}{|c|}{ اسماء المتغيرات } & المتفير ات \\
\hline \multicolumn{5}{|c|}{ 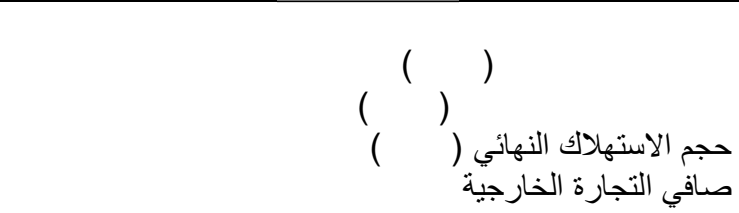 } & $\begin{array}{l}X_{1} \\
X_{2} \\
X_{3} \\
X_{4}\end{array}$ \\
\hline المقار ات & المعاملات & $\begin{array}{c}\text { (t) } \\
\text { (ختبار }\end{array}$ & لدرجات & الاختبار ات & مصفو هـ \\
\hline Constant & 977228 & 8.25 & 1 & $\mathrm{R}^{2}=88.2 \%$ & \\
\hline $\mathrm{X}_{4}$ & 2.3775 & 10.57 & $\begin{array}{l}15 \\
16 \\
\end{array}$ & $\begin{array}{c}\mathrm{R}^{-2}=87.4 \% \\
\mathrm{~F}=111.77 \\
\mathrm{DW}=1.92\end{array}$ & \\
\hline
\end{tabular}

المصدر : الجدول من إعداد الباحث بالاعتماد على مخرجات الحاسبة الالكترونية.

إن قيمة معامل التحديد لهذا الانموذج نبين ان (88.2\%) من التغيرات

الحاصلة في حجم الناتج المحلي الإجمالي للسعودية تعــود إلــى صــــي 
[75]

التجارة الخارجية، وان النسبة المنبقية (11.8\%) تعود إلى تاتير متغير ات اخرى لم تلخل ضمن هدا الانمودج يطلق عليها عـــادة تســمية المتغيــر العشو ائي.

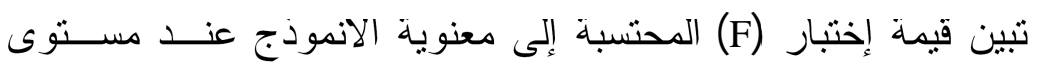

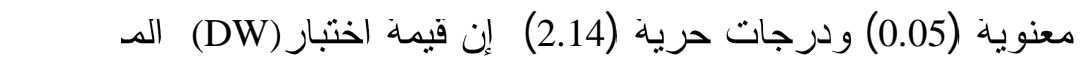
تؤكد عدم وجود مشكلة الارنباط الداتي بين قيم المتغير العشو ائي في هذا الانمودج.

تظهر نتائج التقدير لهذا الانموذج إن هناك علاقة طردية ذات تـاثير

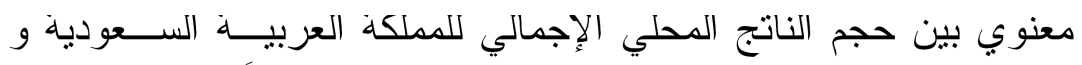

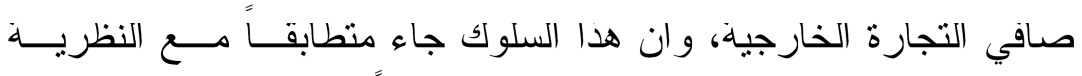

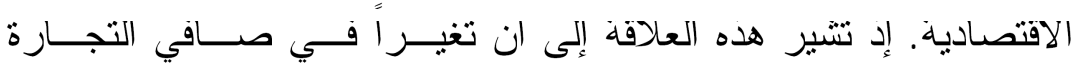

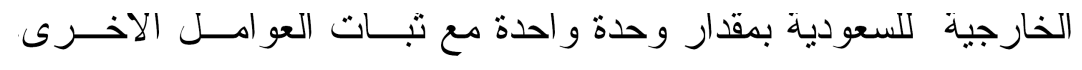

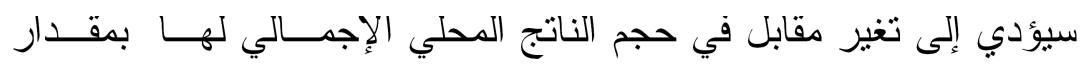
(2.3775) وحدة.

تقدير داله الناتج المحلي الإجمالي لسلطنه عمان للمدة (1992-2006) للحصول على افضل توفيق للانمودج فقد تمث الاستعانة بــالانمودج

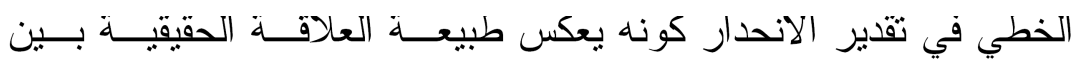
المتغير ات المستقلة و المتغير التابع المستخدمين في هدا التحليل.

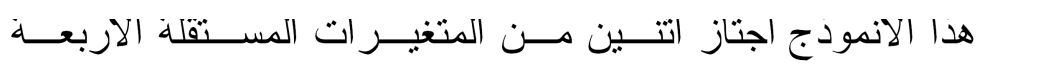

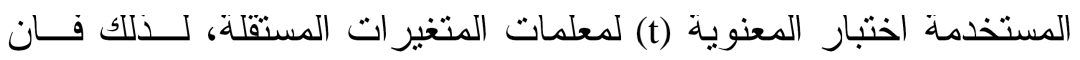
تقدير الانموذج جاء كما ياتي: $Y=173.6+1.17277 X_{3}+1.07262 X_{4}$ (0.23) (14.95) 
در اسات إقليمية 6 (18) [76]

الجدول (7): تقدير داله الناتج المحلي الإجمالي لسلطنه عمان للمدة (1992 -2006)

\begin{tabular}{|c|c|c|c|c|c|}
\hline \multicolumn{5}{|c|}{ اسماء المتفيرات } & \multirow{2}{*}{$\begin{array}{c}\text { المتغير ات } \\
Y \\
X_{1} \\
X_{2} \\
X_{3} \\
X_{4} \\
\end{array}$} \\
\hline \multicolumn{5}{|c|}{ نار حئية } & \\
\hline المقدرات & المعاملات & (t) اختبار & درجات الحريه & الاختبارات & مصفو فه الارتباط \\
\hline $\begin{array}{c}\text { Constan } \\
t\end{array}$ & 173.6 & 0.23 & 2 & $\mathrm{R}^{2}=99.7 \%$ & $\mathrm{X} 3$ \\
\hline $\mathrm{X}_{3}$ & $\begin{array}{c}1.1727 \\
7\end{array}$ & 14.95 & 12 & $\mathrm{R}^{-2}=99.7 \%$ & $\begin{array}{ll}\text { X4 } & 0.917\end{array}$ \\
\hline $\mathrm{X}_{4}$ & $\begin{array}{c}1.0726 \\
2 \\
\end{array}$ & 12.69 & 14 & $\mathrm{~F}=2290.88$ & \\
\hline & & & & $\mathrm{DW}=2.56$ & \\
\hline
\end{tabular}

المصدر : الجدول من إعداد الباحث بالاعتماد على مخرجات الحاسبة الآكترونية.

إن قيمة معامل التحديد لهذا الانمودج نبين ان (99.7) من التغيرات

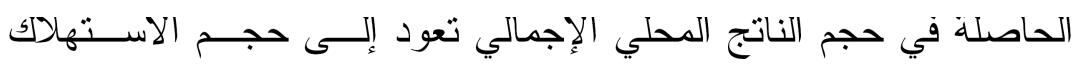

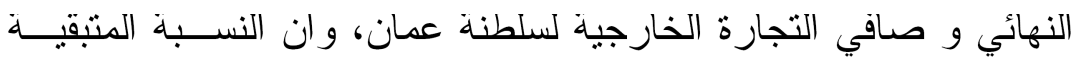
وهي جدَ صغيرة (0.3\%) تعود إلى تاثير متغير ات اخرى لم تلخخل ضمن هذا الانموذج تسمى عادة بالمتغير العشو ائي.

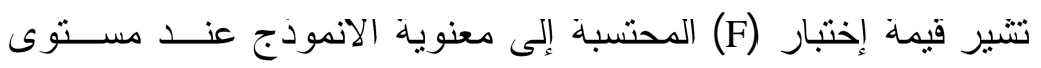

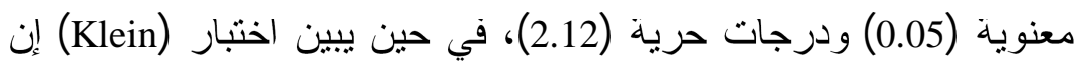
الانمودج لا يعاني من مشكلة الارنباط الخطي بين المتغير ات المســنقلة.

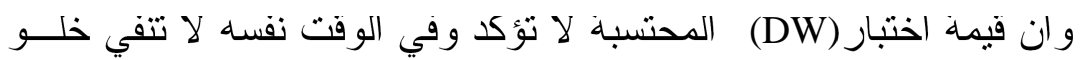

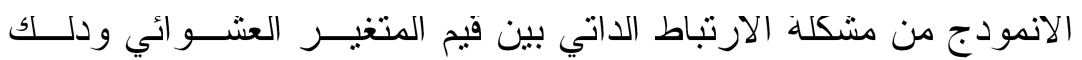
لوقوعها في منطقة عدم التوكد التي يكون فيها القرار غير التئ محسوم. 
إن اختبار تحليل البو اقي قائم على استبعاد القيم التشاذة من القياس، التي

تؤدي إلى زيادة تباينات الاخطاء و التي بدور ها ستزيد من مشناكل القياس،

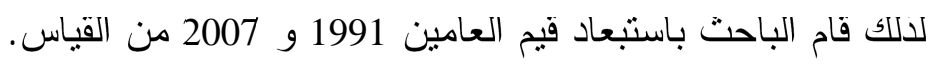
تشير نتائج التقدير لهذا الانمودج إلى إن هناك علاقة طردية دات تاتير

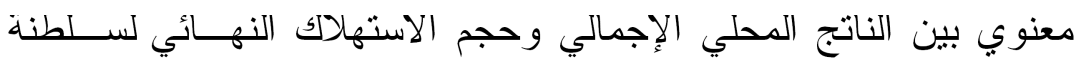
عمان، كما إن هذه العلاقة جاءت منطابقة مع النظرية الاقتصادية. فه مي الإني

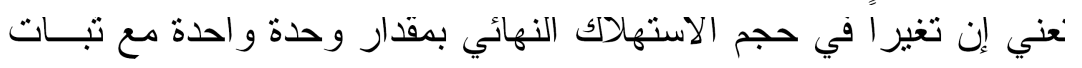
العو امل الاخرى, سيؤدي إلى تغير مقابل في حجم الناتج المحلي الإجمالي بمقدار (1.17277) وحدة.

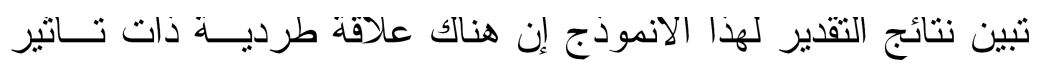

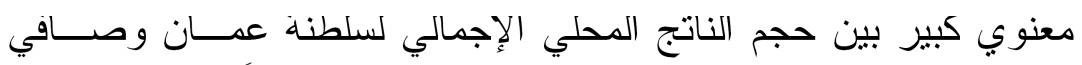

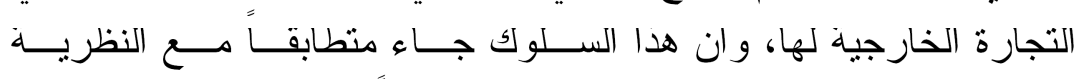

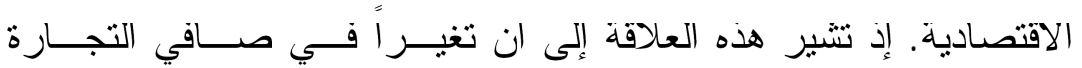

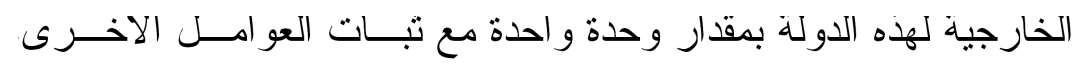

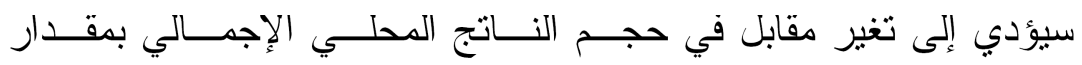
(1.07262)

تحليل المسار في سلطنه عمان: - رده

لقد تم اعتماد قيم معاملات الارتباط المبينة في مصفوفة الارتباط ضمن الجدول (8) في تحليل المسار، د تم تجزئة معاملات الارتباط إلى تاتيرات

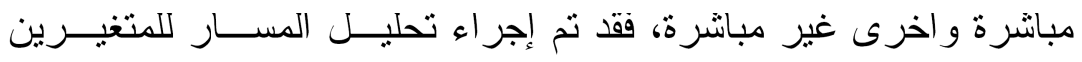

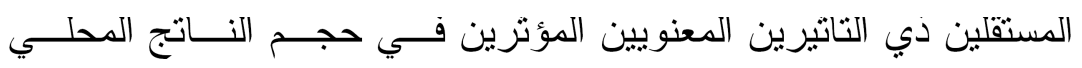
الإجمالي في سلطنة عمان وكما هو موضح في الجدول الاتي: 
دراسات إقليمية 6 (18)

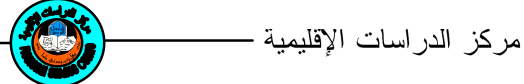

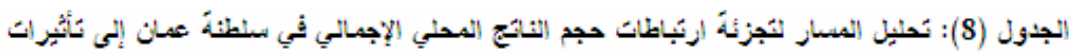

مباثرة وشير مباشرة

\begin{tabular}{|c|c|c|c|}
\hline \\
\hline \multicolumn{4}{|c|}{$\begin{array}{cccc} & & & \\
X_{3} & X_{4} & Y & \\
1.0000 & & & \\
0.9166 & 1.0000 & & \\
0.9810 & 0.9740 & 1.0000 & \end{array}$} \\
\hline \multirow{2}{*}{\multicolumn{4}{|c|}{$\begin{array}{lll} & & \\
\mathrm{S}_{3} & 0.55182 & \\
\mathrm{X}_{3} & 0.46822 & \end{array}$}} \\
\hline & & & \\
\hline الثاتئع الثحلئي & صلقافي لتجازة النارجية & حجم الاستهلاك التهبي & النتظيرت \\
\hline 0.9810 & 0.429170452 & $(0.55182)$ & حجم الاستهلآك التهبئي \\
\hline 0.9740 & $(0.46822)$ & 0.505798212 & صلافي لتجارة التارجية \\
\hline
\end{tabular}

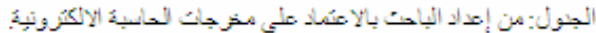

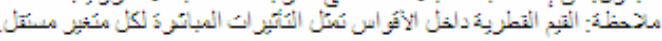

من الجدول (8) الدي يمنل تحليل المسار لتجزئهة ارتباطــات النــاتج

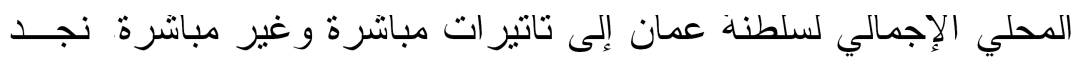

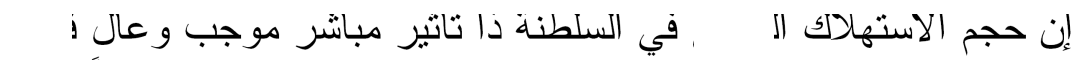

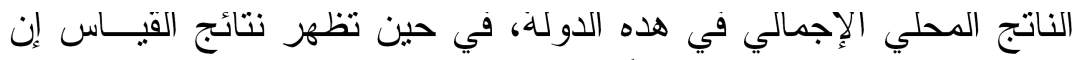

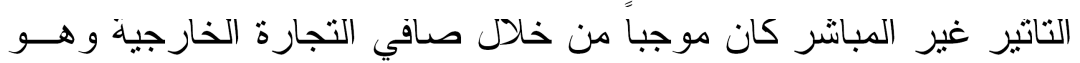
دو تاتير عال. و على وفق النتيجة السابقة وفيما يخص التاتير ات المباشرة، فقد كــان

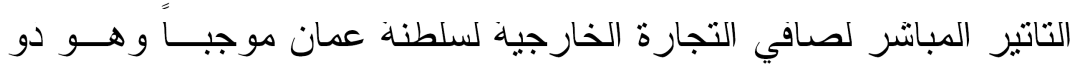

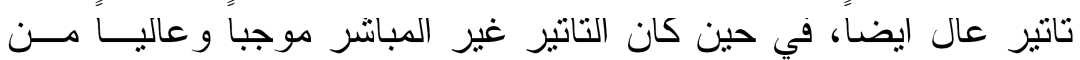
خلال حجم الاستهلاك النهائي. اخير ا وفي ضوء النتائج الحالية يمكن التوصبة باعتماد حجم الاستهلاكك

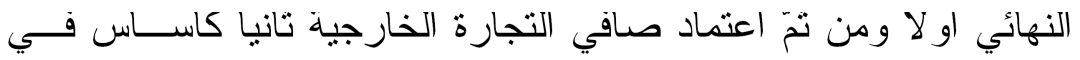
تحديد العو امل المؤترة في الناتج المحلي الإجمالي لسلطنة عمان. 
[79]

د. عبدالله فاضل الحيالي لانضمام إلى منظمة التجارة العالمية -

تقدير داله الناتج المحلي الإجمالي لدوله وطر للمدة (1991-2007) للحصول على افضل توفيق للانموذج فقد تمت الاستعانة بــالانموذج

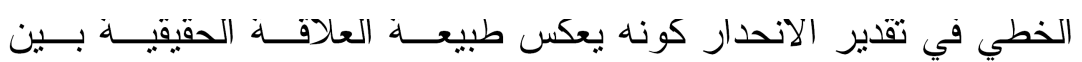
المتغير ات المستقلة و المتغير التابع المستخدمين في هذا التحليل.

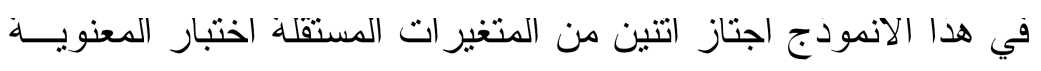

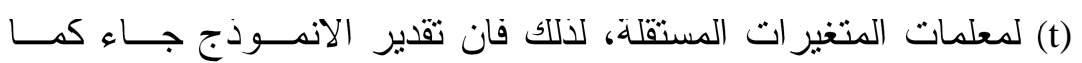
$Y=3907+1.6535 X_{2}+1.0091 X_{4}$ يأتي: -

إن قيمة معامل التحديد لهذا الانموذج تبين ان (4\%) من التغيرات الحاصلة في حجم الناتج المحلي الإجمالي لقطر تعود إلى حجم الاستتمار الإجمالي وصافي التجارة الخارجية لها، وان النسبة المتبقية (1.3\%) تعود إلى تاتير متغير ات اخرى لم تلخخل ضمن هذا الانمودج بطلق عليها عادة تسمية المتغير العشو ائي.

الجدول [9): تقدير داله الناتج المحلي الإجمالي لدوله فطر للمدة (1991 -2007)

\begin{tabular}{|c|c|c|c|c|c|}
\hline \multicolumn{5}{|r|}{ أسماء المتغيرات } & المتغيرات \\
\hline \multicolumn{5}{|c|}{ 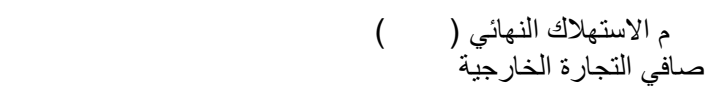 } & $\begin{array}{l}Y \\
X_{1} \\
X_{2} \\
X_{3} \\
X_{4}\end{array}$ \\
\hline & & $(t)$ & الحرية & & \\
\hline $\begin{array}{r}\text { Consta } \\
\mathrm{nt}\end{array}$ & 3907 & 5.58 & 2 & $R^{2}=98.7 \%$ & $\mathrm{x} 2$ \\
\hline$X_{2}$ & 1.6535 & 8.05 & 14 & $R-2=98.5 \%$ & X4 0.930 \\
\hline$X_{4}$ & 1.0091 & 4.11 & 16 & $F=527.03$ & \\
\hline & & & & $\mathrm{DW}=2.41$ & \\
\hline
\end{tabular}

المصدر : الجدول من إعداد الباحث بالاعتماد على مخرجات الحاسبة الالكترونية. 
تبين قيمة إختبار (F) المحتسبة إلى معنوية الانموذج عنـــ مســتوى

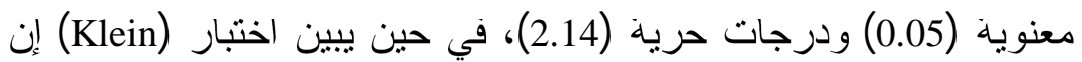

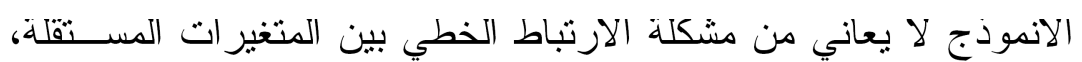
و ان قيمة اختبار (DW) المحتسبة تؤكد عدم وجود مشكلة الارتباط الذاتي لاتي لهاطي بين قيم المتغير العشوائي في هذا الانموذج.

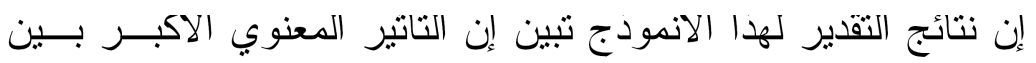

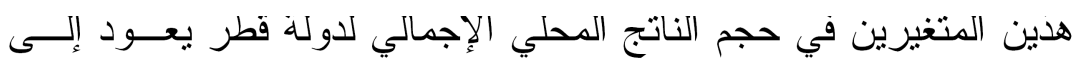

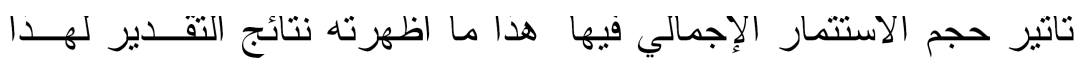

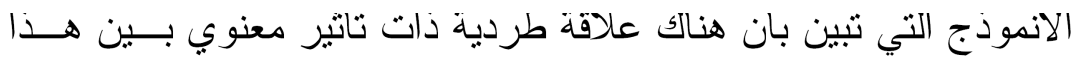

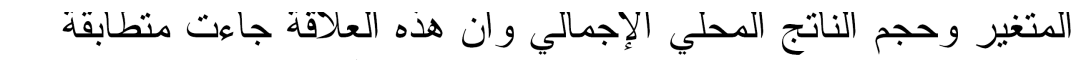

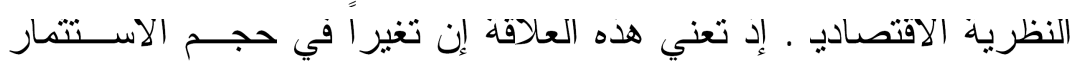

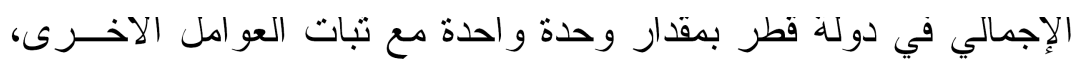
سيؤدي إلى تغير مقابل في الناتج المحلي الإجمالي لها بمة دــدار (1.6535) وحدة. تظهر نتائج التقدير لهذا الانموذج إن هناك علاقة طردية ذات تــاثير معنوي بين حجم الناتج المحلي الإجمالي لدولة قطر و صـــافي التجــارة الخارجية، وان هذا السلوك جاء منطابقا مع النظرية الاقتصادية. إذ نشير النير

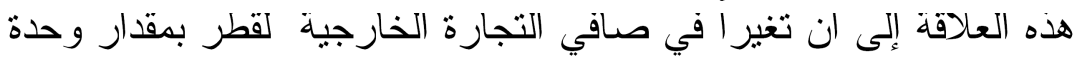
و احدة مع ثبات العو امل الاخرى، سيؤدي إلى تغير مقابل في حجم الناتج المحلي الإجمالي لها بمقدار (1.0091) وحدة.

\section{تحليل المسار في دوله وطر: -}

لقد تم اعتماد قيم معاملات الارتباط المبينة في مصفوفة الارنباط ضمن

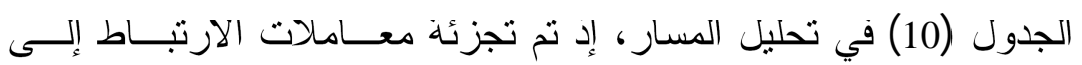


[81]

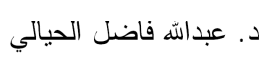
لانضمام إلى منظمة التجارة العالمية

تاثير ات مباشرة واخرى غير مباشرة، فقد تــــ إجــر اء تحليــل المســـار

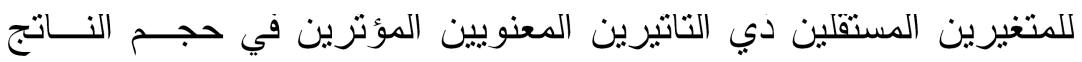
المحلي الإجمالي في دولة قطر وكما هو موضح في الجدول الاتي:

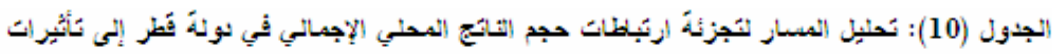
مباشرة وغير مباشرة

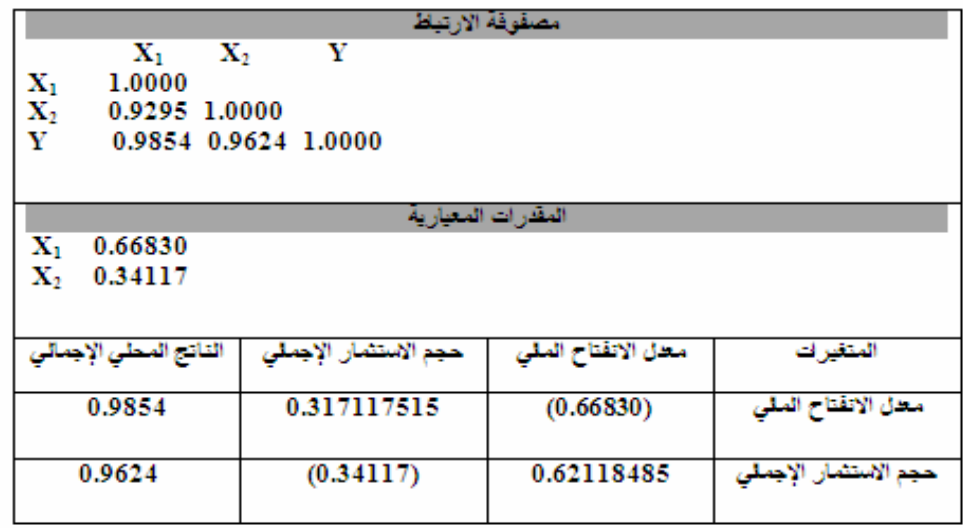

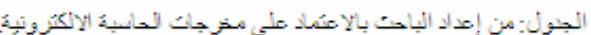

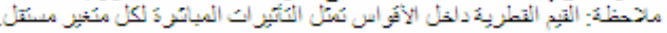

من الجدول (10) الذي يمثل تحليل المسـار لتجزئة ارتباطــات النــاتج المحلي الإجمالي لدولة قطر إلى تاثير ات مباشرة وغير مباشرة، نجـــــ إن معدل الانفتاح المالي في دولة قطر دا تاتير مباشر موجب و عالٍ في الناتج المحلي الإجمالي في هذه الدولة، في حين نظهر نتائج القياس إن التــاثير غير المباشر كان موجبا من خلال حجم الاستتمار الإجمالي وهو دو تاتير علب. و على وفق النتيجة السابقة وفيما يخص التاتير ات المباشرة، فقد كــان التاتير المباشُر لحجم الاستتمار الإجمالي موجبا وهو دو تاتير عال ايضا، 


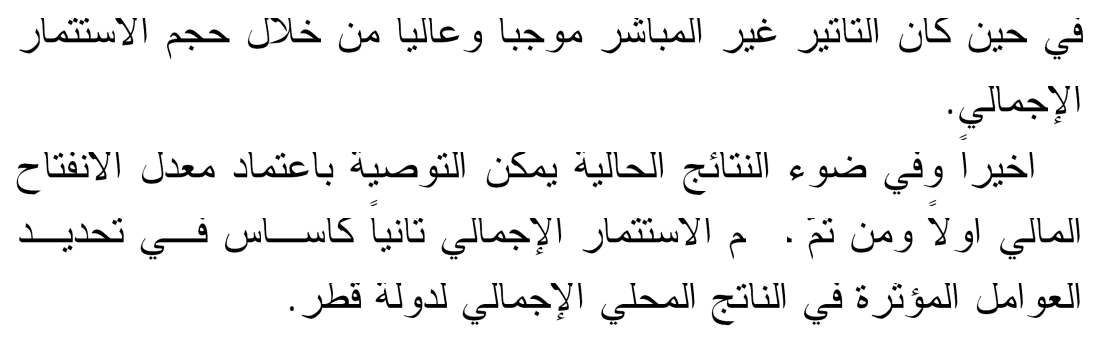

\section{تقدير داله الناتج المحلي الإجمالي لدوله الكويت للمدة (1991-2007)}

للحصول على افضل توفيق للانموذج فقد تمت الاستعانة بــالانموذج

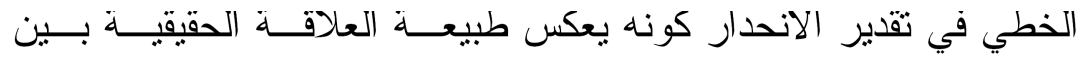

المتغير ات المستقلة و المتغير التابع المستخدمين في هذا التحليل.

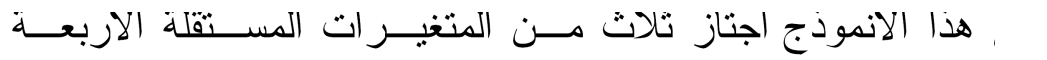

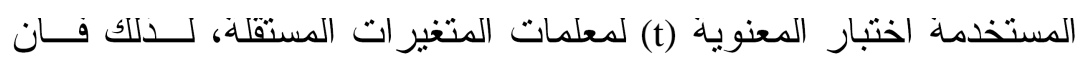

تقدير معلمات الانمودج جاء كما باتي: -

$Y=-4080+1.5124 X_{2}+1.07786 X_{3}+1.06705 X_{4}$

(2.83) (10.77) (15.39)

(27.23) 
[83]

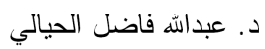
لانضمام إلى منظمة التجارة العالمية

الجدول (11): تقدير داله الناتج المحلي الإجمالي لدوله الكويت للمدة (1991 (2007

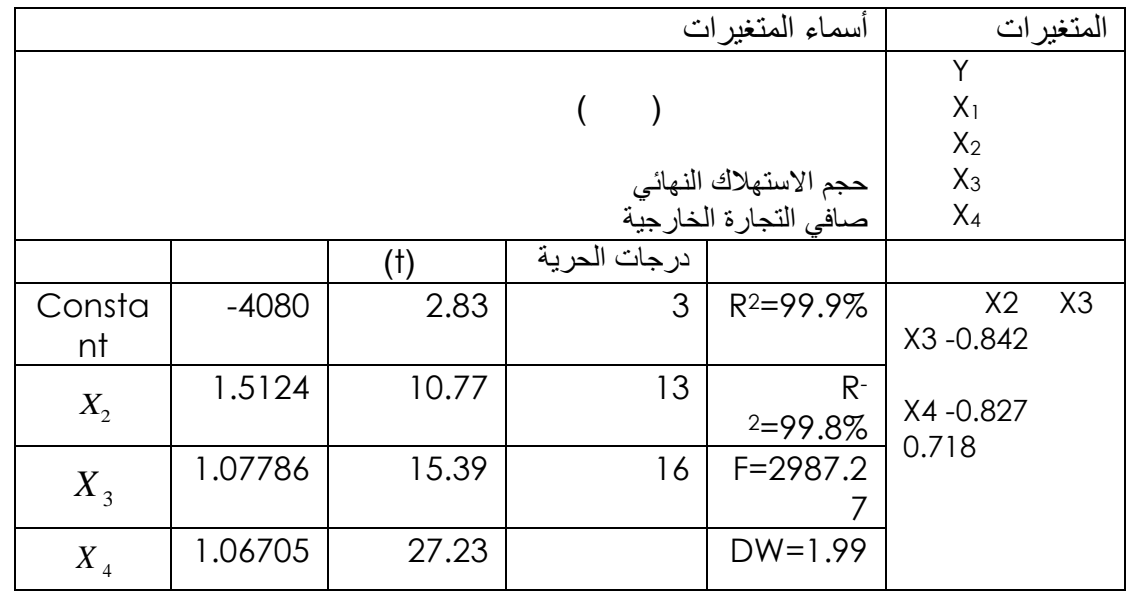
المصدر : الجدول من إعداد الباحث بالاعتماد على مخرجات الحاسبة الالكترونية.

إن قيمة معامل التحديد لهذا الانموذج تبين ان (99.9\%) من التغيرات

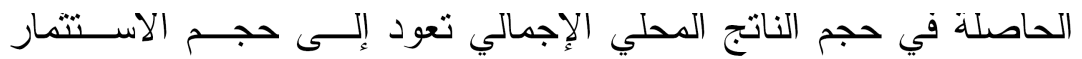

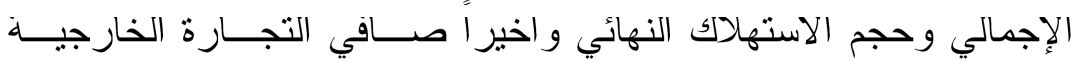
للكويت، وان النسبة المتبقية وهي جدَ صغيرة (0.1\%) تعود إلــى تــاثير

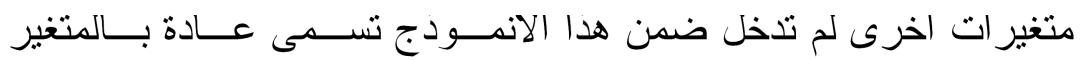
العشو ائي.

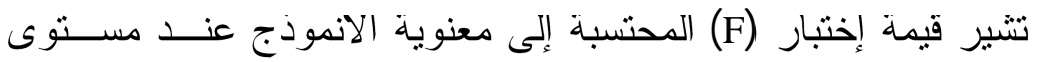

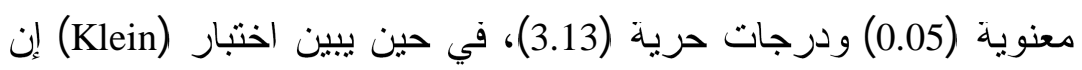
الانموذج لا يعاني من مشكلة الارتباط الخطي بين المتغير ات المســـقنلة.

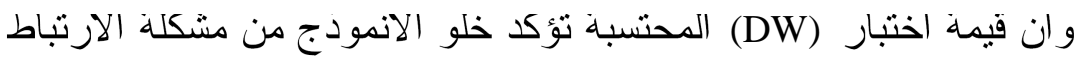

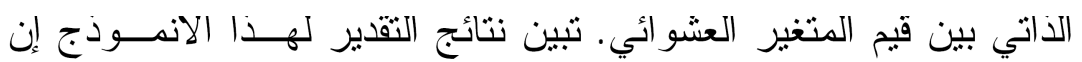
هناك علاقة طردية دات تاتير معنوي بين حجم الناتج المحلي الإجمــالي لئي 
وحجم الاستثمار الإجمالي للكويت، كما إن هذه العلاقة جاءت منطابقة مع

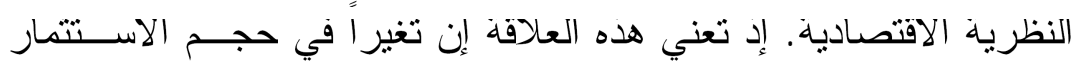

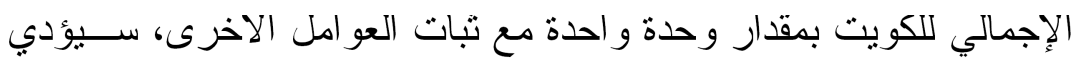
إلى تغير مقابل في الناتج المحلي الإجمالي لها بمقدار (1.5124) وحدة.

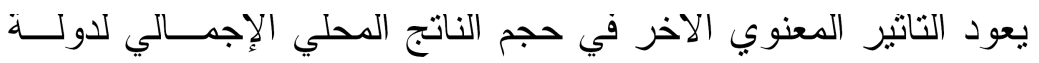

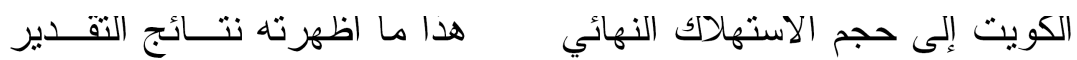

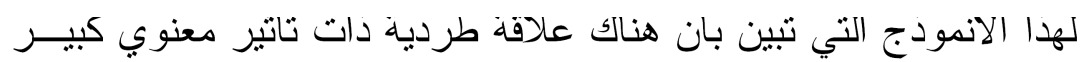

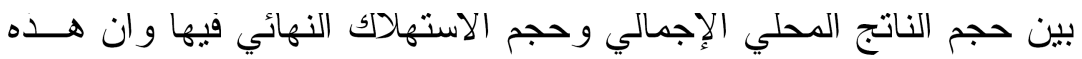
العلاقة كانت متطابقة مع النظرية الاقتصادية، فهي تعني إن تغيــر أ فــي الإني

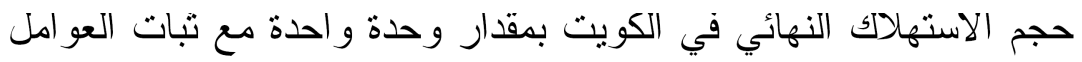
الاخرى, سيؤدي إلى تغير مقابل في حجم الناتج المحلي الإجمالي بمقدار

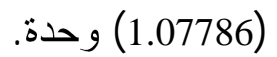

تبين نتائج التقدير لهذا الانموذج إن هناك علاقة طرديــة ذات تــاثير معنوي كبير بين حجم الناتج المحلي الإجمالي للكويت و صـافي التجــارة الخارجية، وان هذا السلوك جاء متطابقا مع النظرية الاقتصادية. إذ نشير

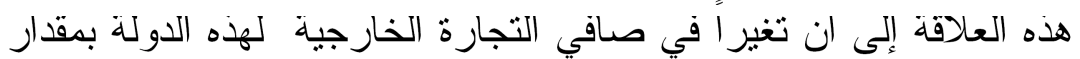
وحدة واحدة مع ثبات العو امل الاخرى، سيؤدي إلى تغير مقابل في حجم الناتج المحلي الإجمالي بمقدار (1.06705) وحدة.

\section{تحليل المسار في الكويت: -}

لقد تم اعتماد قيم معاملات الارتباط المبينة في مصفوفة الارتباط ضمن

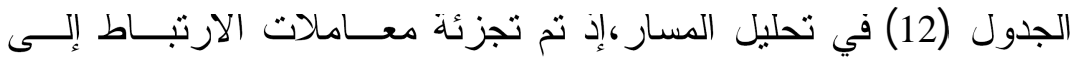

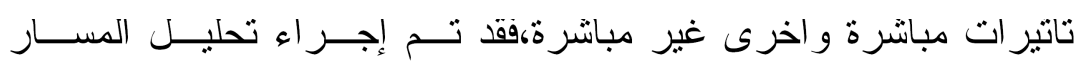


[85]

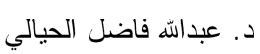
لانضمام إلى منظمة التجارة العالمية

للمتغير ات المستقلة (التناتث) ذات التاثير المعنوي المؤثرة في حجم الناتج

المحلي الإجمالي في دولنة الكويت وكما هو موضح في الجدول الاتي: -

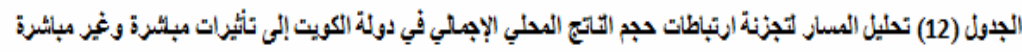

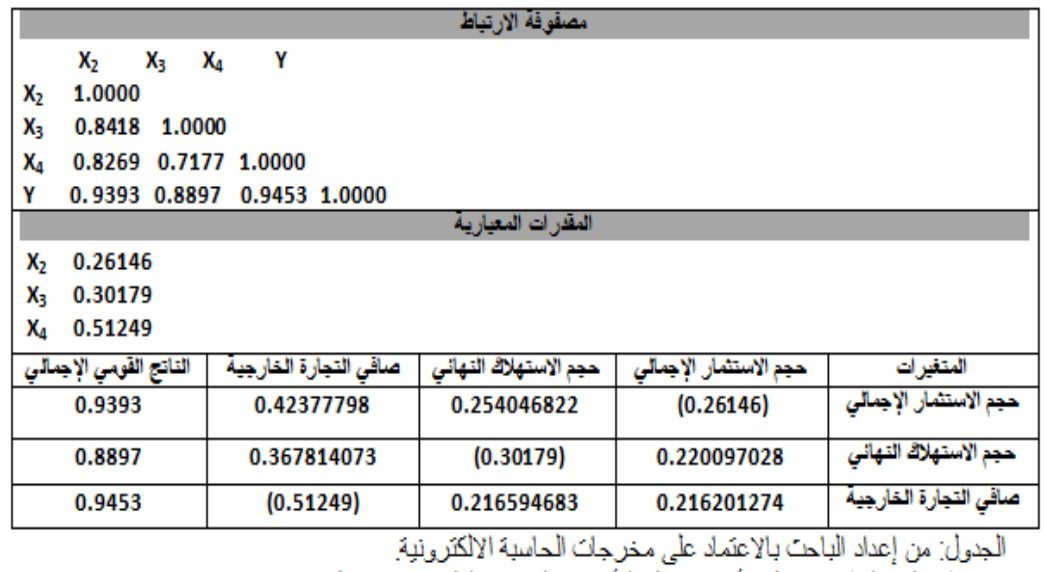

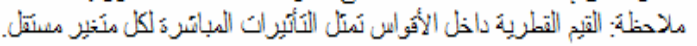

من الجدول (12) الذي يمتل تحليل المسـار لتجزئذ ارتباطــات النـــاتج

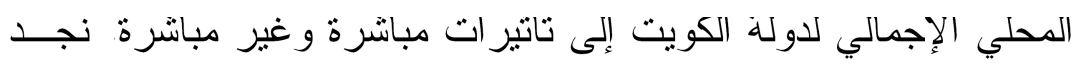
إن حجم الاستثمار الإجمالي ذا تاثير مباشر موجب ولكنه متوسط الفاعلية في الناتج المحلي الإجمالي للكويت، في حين كان التاثير غيــر المباشـــر موجباً وعالياً من خلال صافي التجارة الخارجية وان التاتير غير المباشر من خلال حجم الاستهلاك النهائي كان ايجابيا لكنه متوسط الفاعلية.

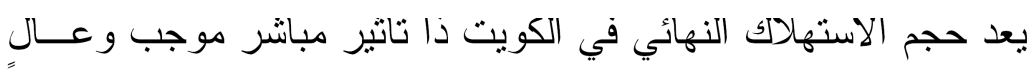

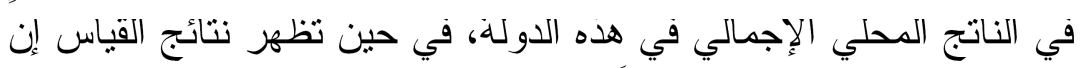

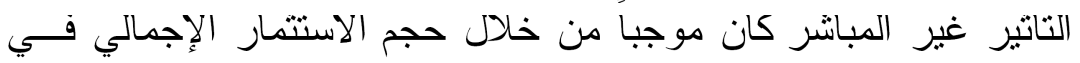
الكويت لكنه كان متوسط التاثير، ونرى إن التاثير غير المباشر من خل خلآل صافي التجارة الخارجية كان ايجابيا وهو دو ناتير عال. 
و على وفق النتيجة السابقة وفيما يخص التاثير ات المباشرة، فقد كـان التاثير المباشر لصافي التجارة الخارجية موجباً وهو ذو تاثير عال ايضاً،

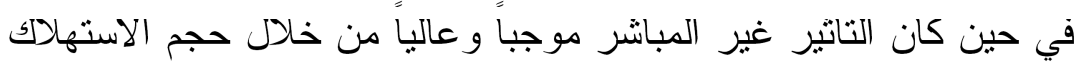

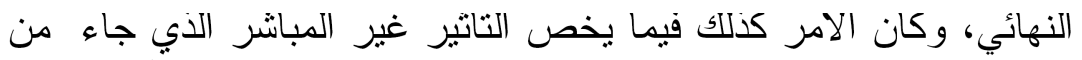

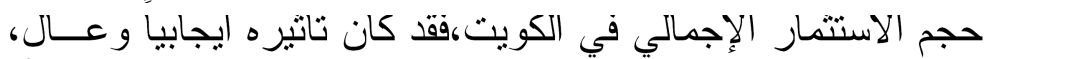
و اخير أ وفي ضوء النتائج الحالية بمكن التوصية باعتماد صافي التجــارة

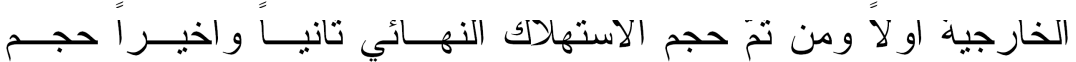
الاستتمار الإجمالي المباشر كاساس في تحديد العوامل المؤنزة في الناتج المحلي الإجمالي لدولة الكويت.

تقير داله النـاتج المحلي الإجمالي لاول مجلس التعاون لـــول الخلـيج (العربيه للمدة (1991-2007) للحصول على افضل توفيق للانموذج فقد تمت الاستعانة بــالانموذج الإن

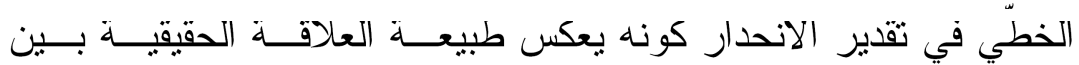
المتغير ات المستقلة و المتغير التابع المستخدمين في هذا التحليل.

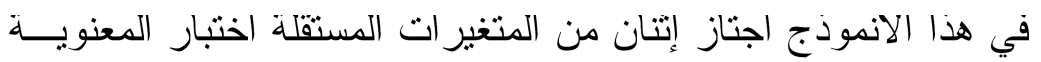
لمعلمات المتغير ات المستقلة، لذلك فان تقدير الانموذج جاء بالثَــكل

$$
Y=-546698+1.8907 X_{1}+2.4790 X_{3}
$$


[87]

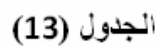

تقدير دائة الناتج المحي الإجماني لدول مجس التعاون لدون الخليج العربية للمدة (1991-2006)

\begin{tabular}{|c|c|c|c|c|c|}
\hline \multicolumn{5}{|c|}{ أسنماء المتنغيرات } & ألمتغبرات \\
\hline \multicolumn{5}{|c|}{ 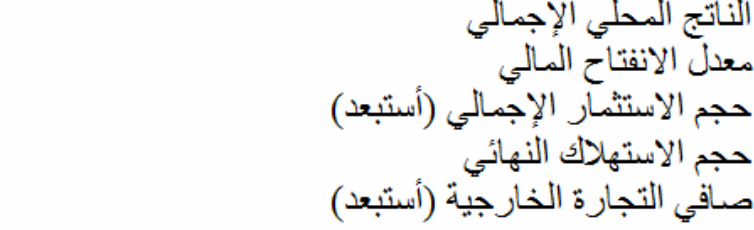 } & $\begin{array}{c}Y \\
X_{1} \\
X_{2} \\
X_{3} \\
X_{4}\end{array}$ \\
\hline ألمقرات & المعاملات & اختبار & لدرجية & الاختبارات & مصفوفة الارتباط \\
\hline Constant & -546698 & 6.40 & 2 & $\mathrm{R}^{2}=96.0 \%$ & \multirow{4}{*}{\begin{tabular}{cc}
\multicolumn{1}{c}{ X1 } \\
X3 & 0.922
\end{tabular}} \\
\hline$X_{1}$ & 18907 & 5.20 & 11 & $\mathrm{R}^{-2}=95.3 \%$ & \\
\hline$X_{3}$ & 2.4790 & 16.22 & 13 & $F=132.58$ & \\
\hline & & & & $D W=1.62$ & \\
\hline
\end{tabular}

إن قيمة معامل التحديد لهذا الانموذج تبين ان (96.0\%) من التغيرات

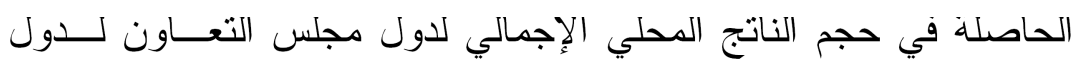
الخليج العربية تعود إلى معدل الانفتاح المالي و حجم الاستهلاكك النهــائي

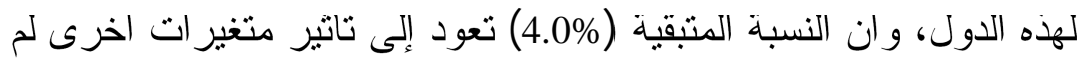
تذخل ضمن هذا الانموذج تسمى عادة بالمتغير العشو ائي.

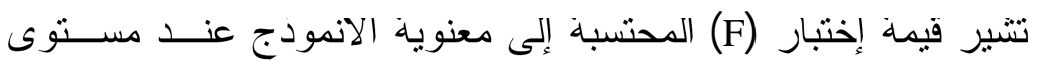

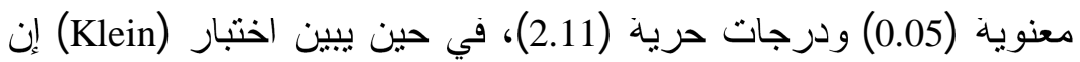
الانمودج لا يعاني من مشكلة الارتباط الخطي بين المتغير ات المســنقلة.

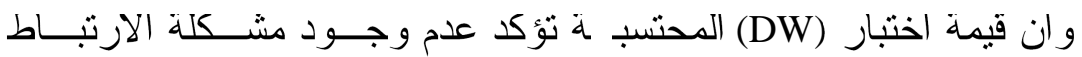
الذاتي بين قيم المتغير العشّوائي. 
إن اختبار تحليل البو اقي قائم على استبعاد القيم الثشاذة من القياس، التي تؤدي إلى زيادة تباينات الاخطاء و التي بدور ها ستزيد من مشاكل القياس، لذلك قام الباحث باستبعاد قيم السنو ات 1994 و 2005و 2007 من القياس. إن نتائج التقدير لهذا الانمودج تبين ان هناك علاقة طردية دات تاتير

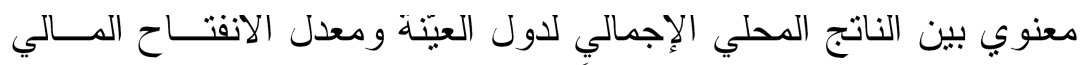

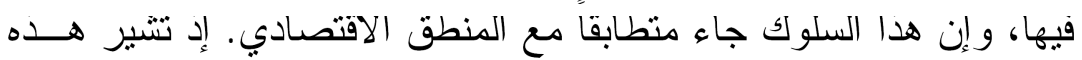

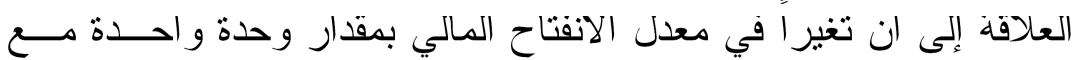

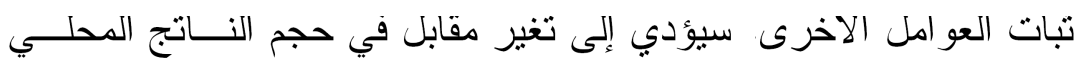
الإجمالي لهذه الدول بمقدار (1.8907) وحدة.

إن التاتير المعنوي الاكبر في حجم الناتج المحلي الإجمالي لدول العينّة يعود إلى حجم الاستهلاك النهائي فيها، هذا ما اظهرته نتائج التقدير لهذا الانموذج التي تبين بان هناك علاقة طردية ذات تاثير معنوي كبير بــين

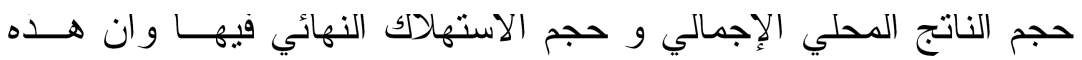
العلاقة كانت متطابقة مع النظرية الاقتصادية، فهي تعني إن تغيــراً فـي الإني

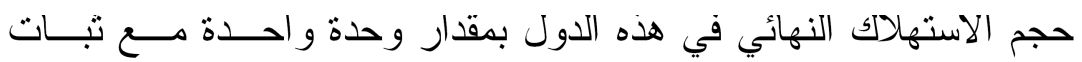
العو امل الاخرى, سيؤدي إلى تغير مقابل في حجم الناتج المحلي الإجمالي ولي بمقدار (2.4790 ) وحدة.

تحليل المسار في دول مجلس التعاون لاول الخليج العربيه: لقد تم اعتماد قيم معاملات الارتباط المبينذة في مصفوفة الارنباط ضمن

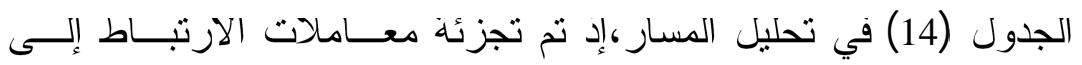

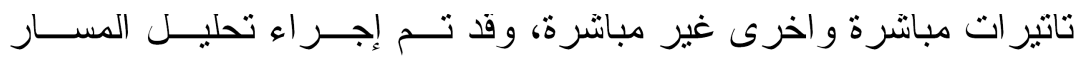

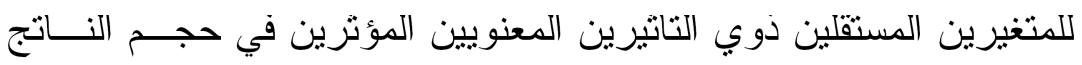
المحلي الإجمالي في دول العينّة وكما هو موضح في الجدول الاتي: - 
[89]

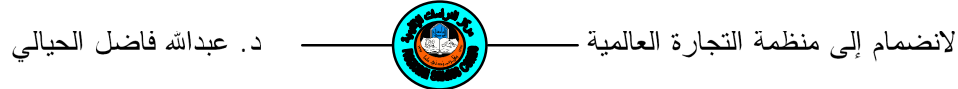

الجدون(14) يبين تحليل المسار لتجزئة ارتباطات حجم النتاتج المحطي الإجماني في دول

مجلس التعاون لدون الخليج العربية إلى تأثيرات مباشرة وغير الثير مباشرة

\begin{tabular}{|c|c|c|c|}
\hline \multicolumn{4}{|c|}{ مصفوفة الارتباط } \\
\hline & $\mathrm{Y}$ & & \\
\hline \multicolumn{4}{|l|}{$\begin{array}{c}\lambda_{1} \\
1.0000\end{array}$} \\
\hline \multicolumn{4}{|c|}{$-0.40241 .0000$} \\
\hline \multicolumn{4}{|c|}{$\begin{array}{lll}-0.0874 & 0.9287 & 1.0000\end{array}$} \\
\hline \multicolumn{4}{|c|}{ ألمقلرات ألمعيارية } \\
\hline \multirow{2}{*}{\multicolumn{4}{|c|}{$\begin{array}{ll}X_{1} & 0.34151 \\
X & 1\end{array}$}} \\
\hline & & & \\
\hline \multicolumn{4}{|c|}{ 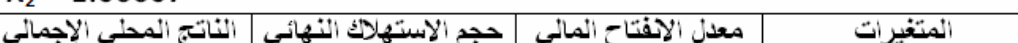 } \\
\hline-0.0874 & -0.428986568 & $(0.34151)$ & معدل الالفتتاح المائي \\
\hline 0.9287 & (1.06607) & -0.137423624 & حجم الاستهلالك النهائي \\
\hline
\end{tabular}

ملاحظة: انقيم القطرية داخل الأقو أس تمثل التثاثثرات المباشرة لكل متغير مستقل.

من الجدول (14) الذي يمتل تحليل المسار لتجزئة ارتباطــات النــاتج

المحلي الإجمالي لدول العيّنة إلى تاثير ات مباشرة وغير مباشرة، نجد إن

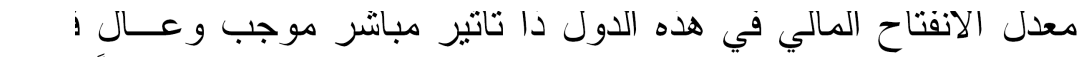

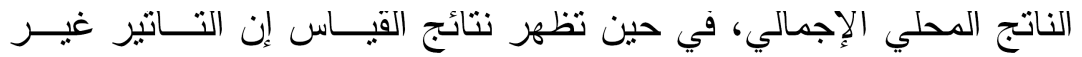

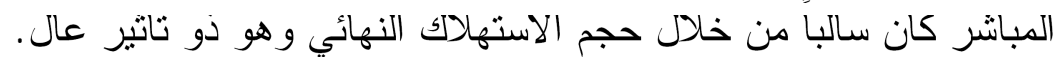

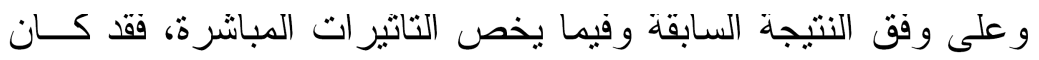

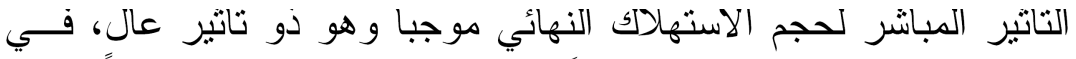
حين كان التاثير غير المباشر سالبا وقليل من خلال معدل الانفتاح المالي.

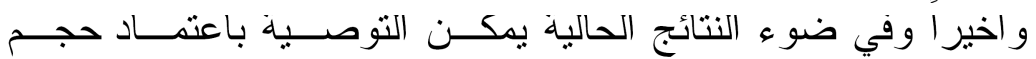

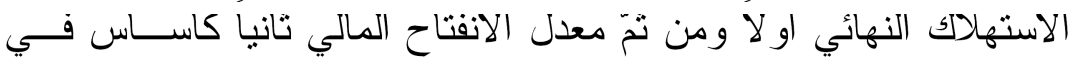
تحديد العو امل المؤتزة في الناتج المحلي الإجمالي لهده الدول. 
الاستنتاجات و المفترحاث

$$
\text { توصل البحت إلى الاستتناجات الاتية: - }
$$

1. يعزَ التحرير المالي المنافسة في الاسواق المالية رو يحسَن كفاءة اداء

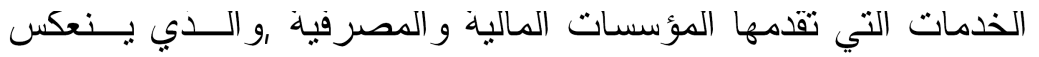
إيجاباً على نو عية الخدمة المالية،وتوفير خيار ات افضل لمستهلكيها.

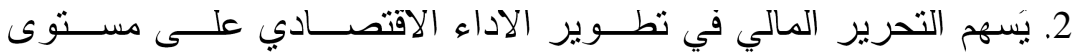
المتغبرات الاقتصادية الكلية, من خلال تتشيط خدمات الوساطة المالية,

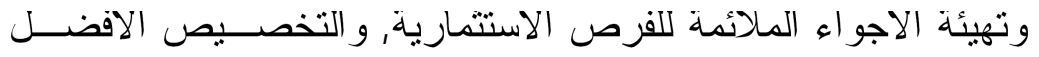
للمو ارد بين القطاعات الاقتصادية وبين الدول المختلفة. 3. يُسهل التحرير المالي عملية حصول الحكومة على المـــوارد الماليــة وبتكاليف ادنى لتمويل قطاعاتها الاقتصادية, فضلا عن حفز هن ها لإدارة السياسات الاقتصادية الكلية , وسياسات الإشر اف و الرقابة على القطاع المالي بشكل كفء، بهذف جذب الاستثمار ات الاجنبيــة، مـ ع ع إعــادة

$$
\text { ارصدة المستثمرين المحليين الموجودة في الخارج. }
$$

4. يؤدي التحرير المالي إلى تهميش المؤسسات المالية المحلية إذا لم يجر الاستعداد الكافي من حيث إصلاح نظامها المالي وتكييفه, و إعادة هيكلة

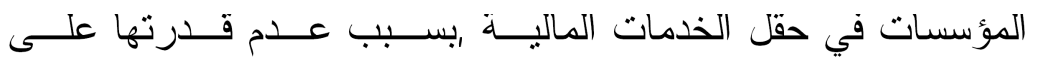
المنافسة,اذ يترتب عليها منافسة مؤسسات مالية عالمية، تتميز بمستوى

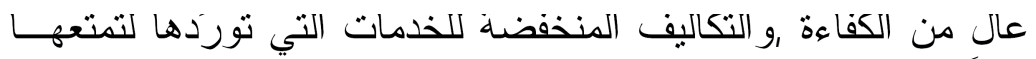

$$
\text { بمزيات الحجم الكبير . }
$$

5. يعني التحرير المالي الاندماج في النظام المالي العالمي و المشاركة في

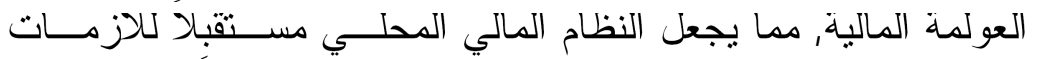

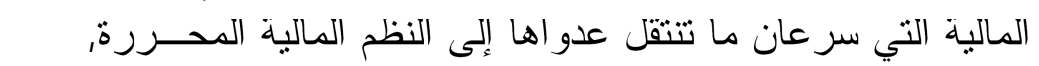

$$
\text { يقوَض من استقر ارها. }
$$


6. اثبت التحليل الكمي ان التحرير المالي للاول الخليجية العربية منفردة

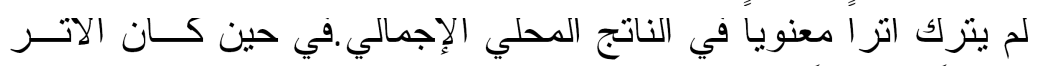

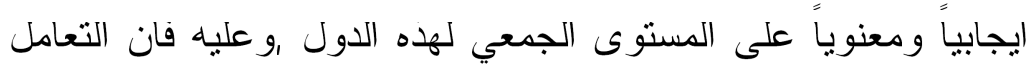

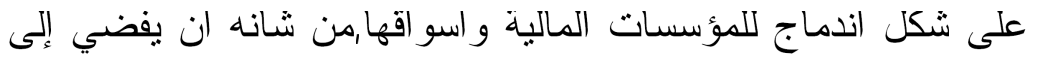

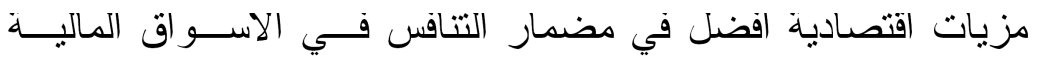

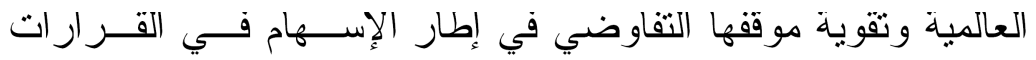

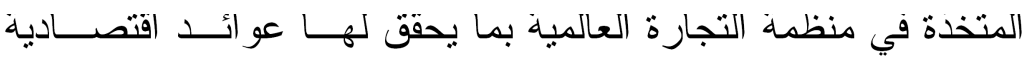
ملموسـة. وتوصل البحث إلى المقترحات الاتية: 1. يجدر بالدول التي تقدم على التحرير المالي ان تقوم ابتــداء بإصــلاح نظامها المالي وتكبيفه بغية تهيئنه للمنافسة المستقبلية بشكل فعَال على بلى لئي المستوى الدولي.

2. ينبغي إعادة هيكلة مؤسسات الخدمة المالية قبل الولــوج فــي عمليــة التحرير المالي ودلك بالتحول إلى الاندماج وتنكوين كيانات كبيرة قادرة

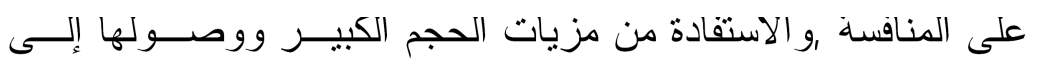

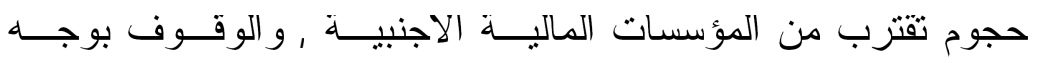
ممارساتها الاحتكارية. 3. يتزتب على المصسارف المركزية و السلطات النقدية في الدول الخليجية العربية ان تمارس دوراً افضل من خلادل ثقوية قــدر اتها الإشـــر افية و الرقابية والتنظيمية على القطاعات المالية فيها وبخاصة في المر احل

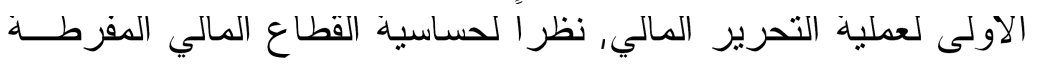
للتقلبات في وتيرة رؤوس الامو ال المحلية و الاجنبية. 4. النتسديد على حتمية التكامل المالي الخليجي و السير به به باتجاه إنـــدماج

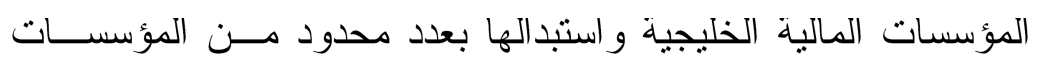




$$
\begin{aligned}
& \text { المالية الضخمة التي تسنطيع منافسة المؤسسات المالية الاجنبية بشكلٍ } \\
& \text { افضل، في ظل تحريز تجارة الخدمات المالية. }
\end{aligned}
$$

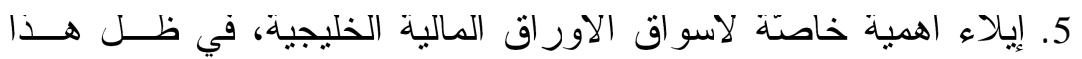

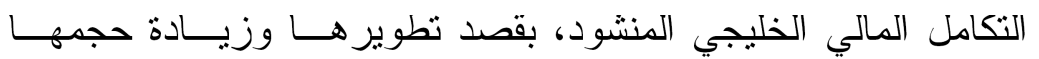

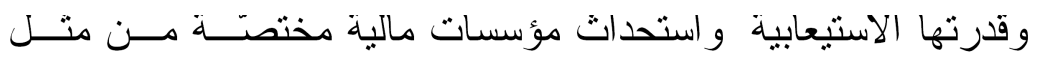

$$
\begin{aligned}
& \text { مصارف الاستثمار وصانعي الاسواق و الوسطاء الماليين. }
\end{aligned}
$$

\title{
The Probable Effects To Access World Trade Organization In The Field of Liberating Financial Services Trade In Economic Growth: Case Studies
}

\author{
Dr Abdullah Fadhil Al-Hayali \\ Lecturer/Dept of Economic \&Social \\ Studies, Regional Studies \\ Centre/University of Mosul
}

\begin{abstract}
Liberating Financial Services trade and its relation with the economic growth is considered a fertile field in international economy. Results of quantitative analysis showed that Financial liberation of Arab Gulf States did not leave Positive and significant effects in Gross Domestic Product, Whereas it was both Positive and significant upon the aggregate level of these states, Therefore, to deal with financial corporations and its markets might lead to achieve better economic features in the field of competition in World Financial markets as well as strengthening its negotiate position in terms of contributing in the decisions of WTO to fulfill tangible economic returns. There should be a kind of stress to aggregate Gulf Financial integration and to be replaced by a limited number of huge financial institutes which can compete foreign
\end{abstract}


[93]

د. عبدالسّة فاضل الحيالي

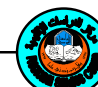
لانضمام إلى منظمة التجارة العالمية

financial institutes in the light of liberating Financial Services Trade. 
(1) حيدر بن عبدالرضا اللواتي، "القطاع المصرفي و المالي في دول مجلس التعاون الخليجي في ظــل

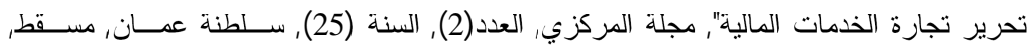

2000, ص 12

(2) عبدالمطلب عبدالحميد، العولمة و اقتصاديات البنوك, الدار الجامعية، الاسكندرية, 2005, ص122.

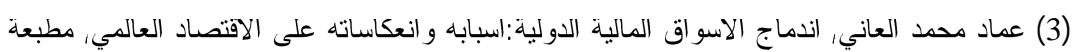

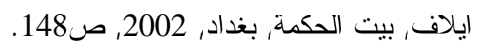

(4) سرمد كوكب الجميل, التمويل الدولي: مدخل في الهياكل و العمليــات و الادو ات, الــــار الجامعيــة

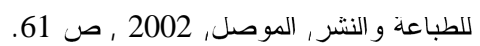

(5) حيدر بن عبدالرضا اللواتي، "القدرة التنافسية للقطاع المصرفي الخليجي في اطار التحليل المالي",

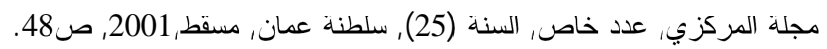

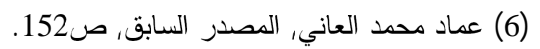

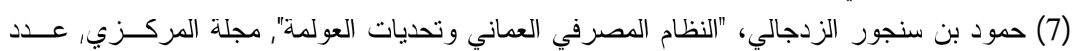

خاص, المصدر السابق , ص24 (1)

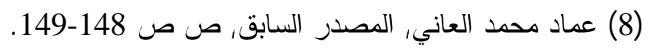

(9) احمد طارق الاغا، اثز تحرير تجارة الخدمات (على) النمو الاقتصادي في بلدان ناميــة مختــارة،

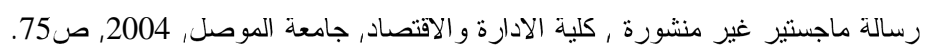

(10) حيدر بن عبدالرضا اللو اتي، "القدرة التنافسبة للقطاع المصرفي الخليجي في اطار التحليل المالي",

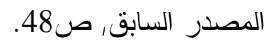

(11) Luis AMajlif, and Simonetta Zarrilli, Challenging Conventional Wisdom: Implications of Trade in Services Liberalization, Trade, Poverty and Gross: Cutting Development Issues study, Series No(2), UNCTAD, UN, New York and Geneva, 2007,pp19 - 20.

$$
\text { (12) احمد طارق الاغا, المصدر السابق, ص77. }
$$

(13)Masamichi Kono,and Ludgre Shunknecht, Financial Services Trade, Capital Flows and Financial Stability,WTO,Geneva,1998,p1 wwwworldbankorg/research/interest/confs/past/paps 15:16 1 ERAD 198:12

$$
\text { (14) احمد طارق الاغا, المصدر السابق, ص77. }
$$

(15) Arturo Galindo, Financial Liberalization and Growth: Empirical Evidence, World Bank, 2002, pp.2-3.

$$
\text { (16) احمد طارق الاغا, المصدر السابق, ص77. }
$$


[95] لانضمام إلى منظمة التجارة العالمية _ـ _.

(17) عبدالمطلب عبدالحميد, الجات و اليات منظمة التجارة العالميـة، الــــار الجامعيــة، الاســكندرية،

2005، ص ص ص ص صن 149-155.

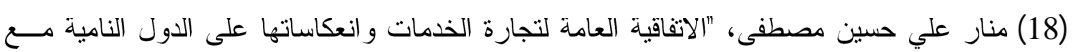

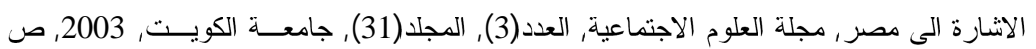

ص 299 -601- (19)

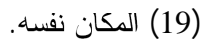

(20) (20)

(21) L Achy, Financial Liberalization, Saving ,Investment and Growth in MENA countries ,2003

wwweconwpa Wustledu /eps /fin /paperspdf

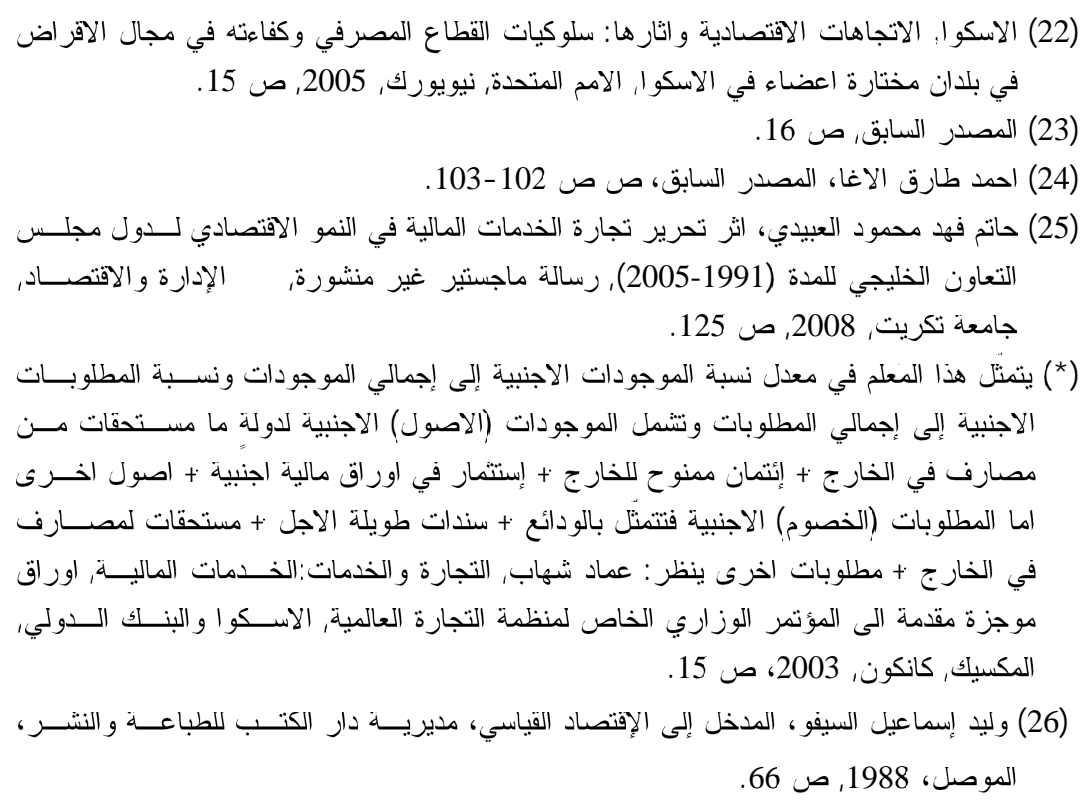

(27) Douglas RDewey and KHLu, A correlation and path: coefficient Analysis of components of Crested Wheatgrass Seed Production, Agron Journal, vol51, 1959, pp. 515-518.

وكذلك يَنظر :

D Link \& B Mishra, Path Coefficient analysis of yield in rice varieties, Indian J

Agric Sci ,43, New Delhi, 1973, pp 376-379. 